\title{
Chemical composition and colouring agents of Roman mosaic and millefiori glass, studied by electron microprobe analysis and Raman microspectroscopy
}

\author{
V. Gedzevičiūtè • N. Welter • U. Schüssler • C. Weiss
}

Received: 9 September 2008 /Accepted: 19 February 2009/Published online: 6 March 2009

(C) Springer-Verlag 2009

\begin{abstract}
About 100 fragments of Roman mosaic and millefiori glass were stylistically attributed to a Hellenistic type, a Ptolemaic and Romano-Egyptian period type and an early imperial period type. Twelve representative fragments were studied by electron microprobe analysis and Raman microspectroscopy. Eleven of them display a $\mathrm{Na}$ pronounced recipe with low $\mathrm{K}, \mathrm{Mg}$ and $\mathrm{P}$ contents, typical for the Roman period. Minor differences in composition are unsystematic, not reflecting the stylistic classification. Ionic colouring agents are $\mathrm{Mn}^{3+}$ for violet, $\mathrm{Cu}^{2+}$ for light blue, $\mathrm{Co}^{2+}$ for deep blue and $\mathrm{Fe}^{3+}$ for brown translucent colours. Calcium antimonates, lead antimonate and cuprite are the colourants responsible for white, yellow and red colours, respectively, and additionally serve as opacifiers. Mixing of ionic colouring agents and opacifying colourants led to a more differentiated palette of colours. $\mathrm{Pb}$ was used as yellow colouring agent, as a flux material and as a stabiliser for the colourant crystals. The remaining fragment consisting of a K-pronounced but still Na-bearing glass matrix was most likely produced during the Middle Ages or later.
\end{abstract}

\footnotetext{
V. Gedzevičiūtė $\cdot$ C. Weiss

Institut für Altertumswissenschaften,

Residenzplatz 2,

97070 Würzburg, Germany

N. Welter

Institut für Physikalische Chemie, Am Hubland,

97074 Würzburg, Germany

U. Schüssler $(\bowtie)$

Lehrstuhl für Geodynamik und Geomaterialforschung,

Institut für Geographie, Am Hubland,

97074 Würzburg, Germany

e-mail: uli.schuessler@uni-wuerzburg.de
}

Keywords Roman glass · Mosaic glass · Millefiori glass · Raman microspectroscopy · Electron microprobe analysis · Ancient glass composition

\section{Introduction}

Mosaic glass, alternatively described as millefiori glass, represents a very special kind of multifariously coloured artistic glass and was used for the creation of exceptional vessels as well as decoration plates for furniture and various architectonical elements. In Mesopotamia, the earliest manufacture of mosaic glass was substantiated for the second millennium BC. It was the antique Romans, however, who produced this kind of glass for a broader use. In the fifteenth and early sixteenth century this technique was renewed by Venetian artisans and particularly in the nineteenth century an almost exact imitation of the antique techniques of mosaic glass making was established in Venice, as well as in Bohemia and Silesia.

Objects of mosaic glass are composed of a multitude of similar tiny glass sections or segments, which were cut off from a long composite mosaic cane with a more or less complicated and variously coloured pattern. The composite mosaic cane itself was previously made by thin rods of differently coloured glass, which were then fused together in a way to form the favoured combination of colours and the desired pattern. To miniaturise the pattern by reducing the diameter of the cane, the latter, while still hot, was protracted and elongated with the pincers. The thin mosaic cane was then cut crosswise to make small circular sections. To form larger plates of mosaic glass, a number of sections were arranged alongside one another and fused together during a new round of heat treatment. In a further step, these plates were sagged above concave or convex forms 
during another reheating procedure to create vessels, plates, bottles, bowls or the like (Goldstein 1979; Grose 1989; Stern and Schlick-Nolte 1994; Lierke 1999).

The results presented in this paper are the first concerning the composition of the glass recipes and the character of the colouring agents used for the production of Roman mosaic glass. A combination of Raman microspectroscopy and electron microprobe analysis has turned out to be a powerful tool for this purpose (Welter et al. 2007) and was applied to analyse representative pieces of Roman mosaic glass.

\section{Archaeology}

The collection of antiquities in the Martin von Wagner Museum in Würzburg holds about 260 fragments of ancient mosaic glass which are generally attributed to a Roman origin. The pieces were derived (1) from the comprehensive art collection of Martin von Wagner, who was a painter and sculptor, collector of antiquities and art agent of the Bavarian King Ludwig I and (2) also from a collection of Ludwig Brüls, a painter and friend of Martin von Wagner's (Möbius 1962). Most probably, Wagner and Brüls acquired the mosaic glass fragments in Rome. This is supported by the fact that most of the pieces are wrapped in cardboard strips with gilded edges and were polished on their upper surfaces, which was typical for ancient glass fragments deriving from antiquity dealers in Rome. The museum received both collections in 1858 and 1860, respectively. Unfortunately nothing is known about the archaeological sites were the fragments were found. Perhaps for this reason, the pieces initially did not attract the attention of archaeologists and were stored in the museum's magazine. In the course of a recent project, hundred of the mosaic glass fragments were investigated regarding their stylistic provenance (Gedzevičiūtè 2006). From this, a subdivision of the fragments belonging to (1) a Hellenistic type, (2) a Ptolemaic and Romano-Egyptian period type and (3) an early imperial period type could be introduced. The earliest fragments belong to the so-called Canosa-Group of the Hellenistic period and are dated from the late third to the late second century BC (Oliver 1968; Stern and SchlickNolte 1994). Typical characteristics are spiral and radiant patterns, but also small square monochrome segments (tesserae) and segments of sandwich gold-glass (a piece of gold leaf between two layers of colourless glass) which were interspersed between mosaic glass sections. During the imperial period from the middle of the first century BC on, the older patterns are supplemented by new and very variable kinds of ornamentation, by a remarkable increase of translucent and opaque colours and by a wider variety of vessel forms (Grose 1989). The radiant patterns disappear and give place to more complicated, rosette- and flowerlike (millefiori), stonelike and geometrical patterns. The Ptolemaic and Romano-Egyptian period mosaic glass occurs from the third century $\mathrm{BC}$ to the first century $\mathrm{AD}$ and comprises plates and stripes as used e.g. for ornamentation in architecture and inlays for furniture. This type of glass points to a provenance from the Roman Egypt (Grose 1989).

From all hundred fragments, 12 pieces, which are representative for the three groups described above, were selected for analytical studies concerning the following questions:

1. Do the mosaic glass fragments in all their colours match the very homogeneous typical Roman glass receipt?

2. Are all fragments of Roman age, or can we find some glass with older or younger glass compositions?

3. Do we find chemical differences between the three stylistically different groups of the Roman mosaic glass?

4. What are the colouring agents of the translucent and the opaque coloured glass?

\section{Experimental}

\section{Samples}

The representative selection of samples for analytical studies is shown in Fig. 1. The fragments 2 and 6 were attributed to the Hellenistic type; fragments 78, 83, 87 and 93 to the Ptolemaic and Romano-Egyptian period type and fragments 7, 29, 33, 60 and 102 to the early imperial period type. Fragment 103 was preliminarily classified as Ptolemaic-early imperial period type. The samples are composed of differently coloured translucent or opaque glass forming various designs and ornaments. All the fragments are more or less intensively corroded on their lower side due to long storage in soil. On their upper side, however, the corrosion patina was removed and the glass was repolished in the nineteenth century by previous owners of the collections, so that a slight cleaning of the surface with ethanol was sufficient to prepare the samples for quantitative electron microprobe analysis and Raman microspectroscopy. Subsequently, the matrix of all differently coloured glass parts and colouring agents of the translucent glass were measured by electron-microprobe analysis, whereas the Raman method was used to characterise the microcrystals contributing colour and opacity to the various opaque glass parts.

Electron microprobe analysis

Chemical compositions of all the variously coloured glass parts were determined at the Department of Geodynamics 
Fig. 1 Mosaic glasses investigated. Fragments 2 and 6 are attributed to the Hellenistic type, fragments $78,83,87$ and 93 to the Ptolemaic and RomanoEgyptian period type and fragments 7,29,33, 60 and 102 to the early imperial period type. The size of the fragments is $3.2 \mathrm{~cm}$ longest side (2), $2.9 \mathrm{~cm}$ longest side (6), $4.7 \mathrm{~cm}$ height (7), $2.9 \mathrm{~cm}$ longest side (29), $2.8 \mathrm{~cm}$ longest side (33), $1.8 \mathrm{~cm}$ longest diametre (60), $2.2 \mathrm{~cm}$ side (78), $4.7 \mathrm{~cm}$ height (83), $2.6 \mathrm{~cm}$ longitude (87), $3.1 \mathrm{~cm}$ longest diametre (102), $2 \mathrm{~cm}$ height (103)
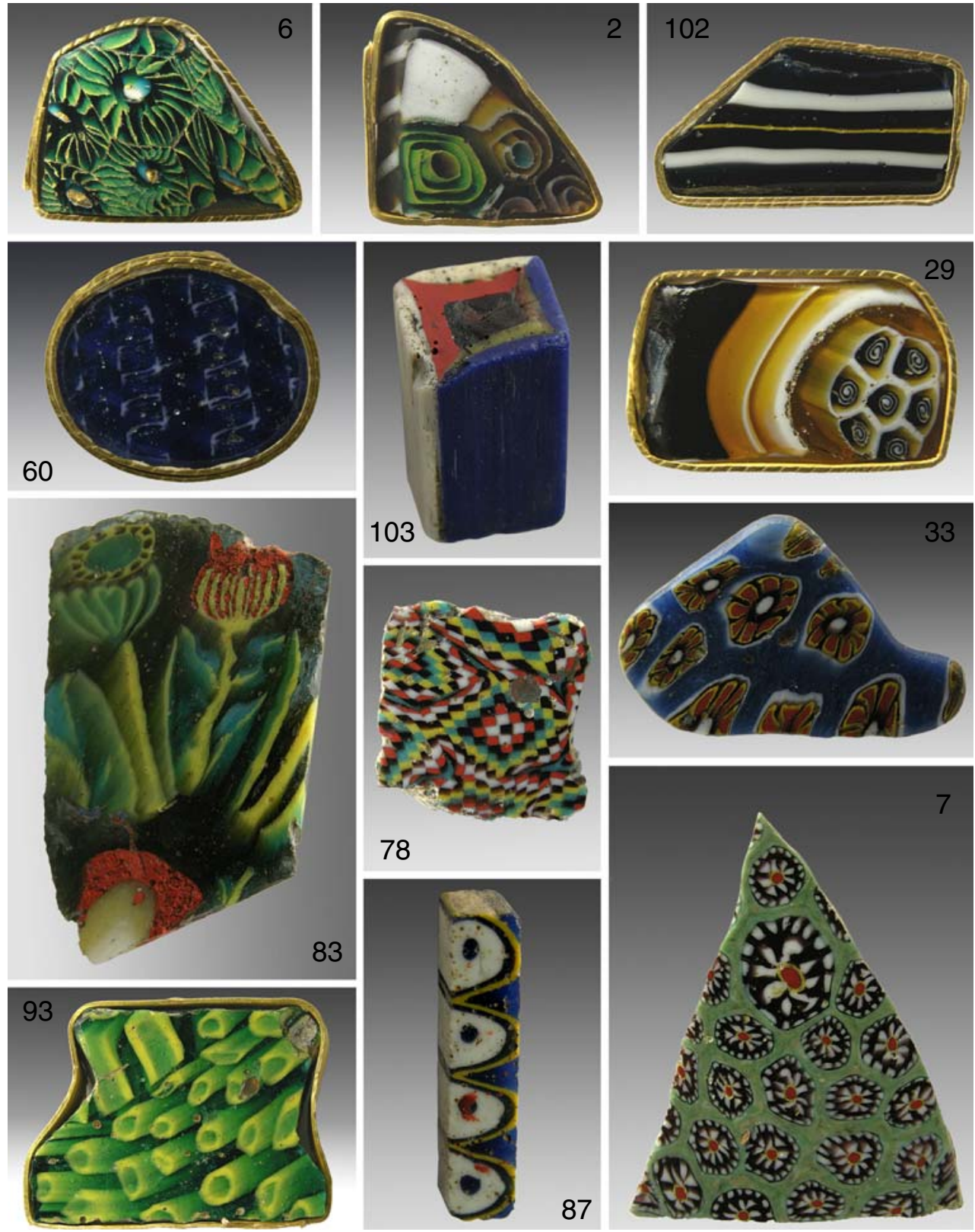

83
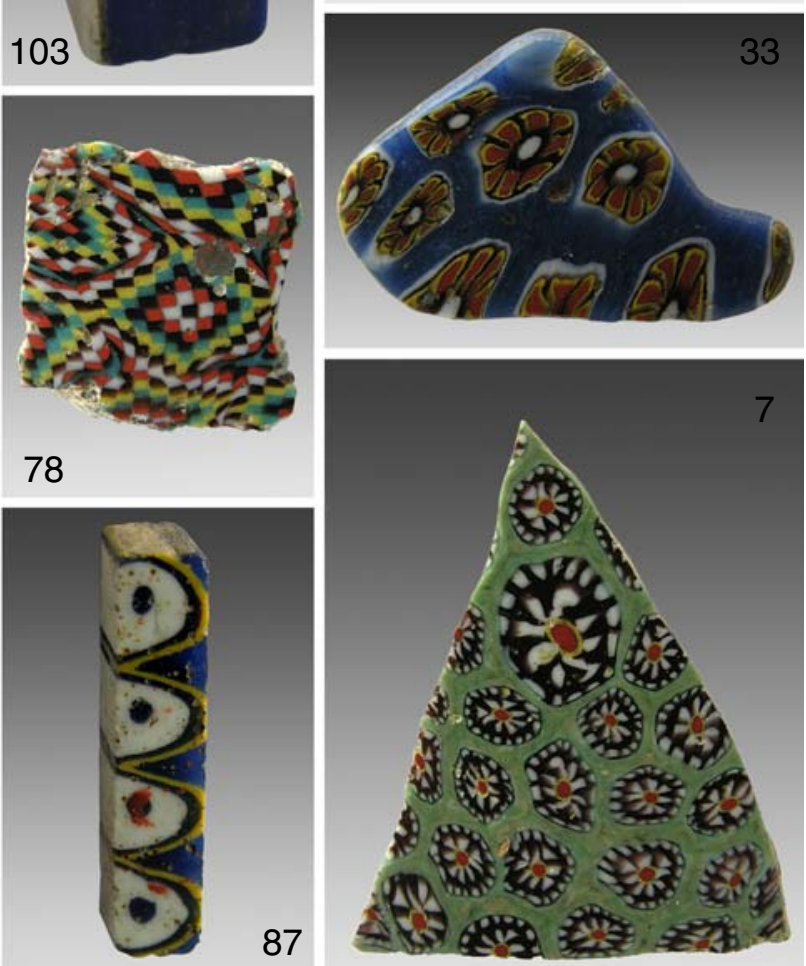

and Geomaterial Science at the University of Würzburg using a CAMECA SX50 electron microprobe with wavelength-dispersive spectrometers, allowing for non-destructive in situ analysis of archaeological finds, if the following requirements are met. The sample must be placed into the microprobe as a whole. A special sample-holder was constructed to allow the insertion of samples as large as $40 \times 55 \times 18 \mathrm{~mm}$ into the vacuum chamber. The cleaning of the polished sample surface was performed with $100 \%$ ethanol. To avoid carbon coating of the whole sample surface, the fragments were enwrapped into aluminium foil with small openings only at the surface locations selected to be analysed. A conduction bridge was made using conducting carbon lacquer, which may later easily be dissolved in acetone. Operating conditions were $15 \mathrm{kV}$ accelerating voltage, $15 \mathrm{nA}$ beam current and $25 \mu \mathrm{m}$ beam size. For glass samples such a large beam size has to be used to avoid thermally induced diffusion of alkali elements during analysis. Of course, the measured chemical composition reflects an integrated composition of the whole area covered by the beam size; for opaque glass this means a total analysis of glass matrix and colouring microcrystals within the radiated area. Element peaks and backgrounds were measured with counting times of $20 \mathrm{~s}$ each, but of $30 \mathrm{~s}$ for $\mathrm{Fe}, \mathrm{Mn}, \mathrm{Cu}$ and $\mathrm{Co}$. For $\mathrm{Sb}$ analysis, the $\mathrm{Sb} \mathrm{L} \beta$ line was used instead of $L \alpha$ to avoid interference with the $\mathrm{K} \mathrm{K} \beta$ line; $\mathrm{P}$ was measured on the $\mathrm{K} \alpha$ line by using the PET monochromator instead of the TAP to avoid interference 
with $\mathrm{Ca} \mathrm{K} \beta$ second order line. Synthetic silicate and oxide minerals or pure elements were used as reference standards. The matrix correction was calculated by the PAP program supplied by CAMECA. An analytical error of less than $1 \%$ relative for major elements is verified by repeated measurements on the respective standards. For low element concentrations, the analytical uncertainty increases. Using these operating conditions, the detection limit is at about 0.03-0.1 wt.\%.

From all 12 fragments, all differently coloured parts were qualitatively analysed by wavelength-dispersive scans and then quantitatively by about five single analysis runs. From these, the average was calculated for the respective glass part. Average compositions of the glass matrices of the various glass samples are given in Table 1 .

To visualise the differences in average atomic number (i.e. general differences in chemical composition) between variously coloured glass as well as the extremely finegrained crystals in the opaque glass parts by means of backscattered electron images, the JEOL JXA-8200 electron microprobe at the Institute of Mineralogy at the University of Erlangen-Nürnberg was used.

\section{Raman microspectroscopy}

All the differently coloured opaque parts of the glass fragments were examined in a non-destructive fashion by Raman microspectroscopy at the Institute for Physical Chemistry of the University of Würzburg. The scattered light was collected in backscattering geometry by focusing a $\times 50$ objective (Olympus ULWD MSPlan50) on the entrance slit of a spectrometer LabRam, Dilor with 1,800 grooves $/ \mathrm{mm}$, respectively 950 grooves $/ \mathrm{mm}$ diffractive grating. The $514.5 \mathrm{~nm}$ line of an argon ion laser (Spectra Physics, Model 166) was applied for excitation.
The laser power at the focus spot with a beam diameter of about $5 \mu \mathrm{m}$ on the sample was kept below $5 \mathrm{~mW}$. The spectral resolution was $4 \mathrm{~cm}^{-1}$. The detection system consisted of a charge-coupled multichannel detector (CCD, SDS 9000 Photometrics). The acquisition of a single spectrum typically took about $10-60 \mathrm{~s}$ for the crystalline phase; about ten accumulations were performed for each Raman spectrum.

\section{Analytical results}

\section{Principal glass composition}

Apart from fragment 103, all glass fragments are composed of a $\mathrm{Na}_{2} \mathrm{O}$-rich sodium-calcium-silicate-glass, which is poor in $\mathrm{K}_{2} \mathrm{O}, \mathrm{MgO}$ and $\mathrm{P}_{2} \mathrm{O}_{5}$, but contains appreciable amounts of $\mathrm{CaO}$ and also $\mathrm{Al}_{2} \mathrm{O}_{3}$. Beside the oxides of $\mathrm{Si}, \mathrm{Al}, \mathrm{Ca}, \mathrm{K}$ and $\mathrm{Na}$, which define the basic composition of the glass recipe, further components are added as colourants or as an additional flux material. To get a common level for a comparison of the basic compositions of the different glass parts, all additional components were subtracted from the analyses before normalizing the basic composition to $100 \%$. This calculation procedure appears appropriate assuming that Roman glassmakers used one widely distributed common recipe with these oxides to produce a basical melt and not till then added the colourants and other additional elements. If the fragments are Roman, the calculated and normalised contents of the five oxides should reflect the Roman basical glass recipe. The variations of the normalised oxides for 11 fragments are $69-77 \%$ for $\mathrm{SiO}_{2}, 2.1-4.3 \%$ for $\mathrm{Al}_{2} \mathrm{O}_{3}, 5.6-11.7 \%$ for $\mathrm{CaO}$, $0.5-2.0 \%$ for $\mathrm{K}_{2} \mathrm{O}$ and $9.4-19.1 \%$ for $\mathrm{Na}_{2} \mathrm{O}$ (Fig. 2a).

Table 1 Average of microprobe analyses of every colour in every fragment

\begin{tabular}{|c|c|c|c|c|c|c|c|c|c|c|c|c|c|c|c|c|}
\hline $\begin{array}{l}\text { Fragment } \\
\text { (wt.\%) }\end{array}$ & $\begin{array}{l}2 \\
\text { white }\end{array}$ & $\begin{array}{l}2 \\
\text { yellow }\end{array}$ & $\begin{array}{l}2 \\
\text { violet }\end{array}$ & $\begin{array}{l}2 \\
\text { brown }\end{array}$ & $\begin{array}{l}2 \\
\text { blue }\end{array}$ & $\begin{array}{l}6 \\
\text { yellow }\end{array}$ & $\begin{array}{l}6 \\
\text { white }\end{array}$ & $\begin{array}{l}6 \\
\text { blue }\end{array}$ & $\begin{array}{l}7 \\
\text { red }\end{array}$ & $\begin{array}{l}7 \\
\text { yellow }\end{array}$ & $\begin{array}{l}7 \\
\text { green }\end{array}$ & $\begin{array}{l}7 \\
\text { white }\end{array}$ & $\begin{array}{l}7 \\
\text { violet }\end{array}$ & $\begin{array}{l}29 \\
\text { brown }\end{array}$ & $\begin{array}{l}29 \\
\text { white }\end{array}$ & $\begin{array}{l}29 \\
\text { brown }\end{array}$ \\
\hline $\mathrm{SiO}_{2}$ & 67.36 & 48.85 & 67.41 & 68.64 & 66.10 & 44.16 & 58.34 & 67.44 & 54.31 & 55.87 & 56.59 & 56.71 & 64.64 & 69.35 & 63.36 & 69.24 \\
\hline $\mathrm{SnO}_{2}$ & 0.06 & 0.08 & $<0.05$ & 0.07 & 0.39 & 0.05 & 0.03 & n.d. & 3.33 & 0.15 & 0.63 & 0.15 & n.d. & $<0.05$ & $<0.05$ & $<0.05$ \\
\hline $\mathrm{Sb}_{2} \mathrm{O}_{3}$ & 5.60 & 1.72 & 0.12 & 0.03 & $<0.05$ & 2.91 & 6.54 & 0.04 & $<0.05$ & 1.44 & 3.72 & 6.29 & 0.15 & $<0.05$ & 7.54 & $<0.05$ \\
\hline $\mathrm{Al}_{2} \mathrm{O}_{3}$ & 2.58 & 1.94 & 2.43 & 2.16 & 2.38 & 2.73 & 2.06 & 2.15 & 2.48 & 2.20 & 2.06 & 2.05 & 2.49 & 2.80 & 2.34 & 2.53 \\
\hline $\mathrm{PbO}$ & $<0.05$ & 26.37 & 0.07 & $<0.05$ & 1.62 & 30.39 & 12.46 & 0.99 & 9.41 & 16.41 & 10.27 & 12.33 & 0.67 & 0.00 & $<0.05$ & $<0.05$ \\
\hline $\mathrm{CuO}$ & $<0.05$ & 0.62 & 0.11 & $<0.05$ & 2.24 & 0.52 & 0.22 & 2.74 & 2.46 & 0.64 & 4.93 & n.d. & n.d. & $<0.05$ & $<0.05$ & $<0.05$ \\
\hline $\mathrm{CoO}$ & n.d. & n.d. & n.d. & n.d. & $<0.03$ & n.d. & n.d. & $<0.03$ & n.d. & n.d. & n.d. & n.d. & 0.03 & n.d. & n.d. & n.d. \\
\hline $\mathrm{FeO}$ & 0.40 & 1.62 & 0.68 & 0.35 & 0.40 & 1.43 & 0.35 & 0.38 & 2.03 & 0.85 & 0.65 & 0.33 & 0.68 & 0.27 & 0.40 & 0.24 \\
\hline $\mathrm{MnO}$ & $<0.05$ & 0.44 & 1.47 & 0.09 & 0.10 & 0.13 & 0.13 & 0.89 & 0.83 & 0.06 & 0.44 & 0.77 & 1.98 & $<0.05$ & 1.30 & 0.07 \\
\hline $\mathrm{CaO}$ & 7.37 & 5.11 & 8.02 & 8.79 & 7.71 & 7.35 & 6.37 & 7.13 & 7.62 & 5.71 & 5.64 & 6.51 & 7.72 & 7.99 & 8.08 & 7.77 \\
\hline $\mathrm{MgO}$ & 0.41 & 0.35 & 0.54 & 0.55 & 0.46 & 0.42 & 0.63 & 0.53 & 0.66 & 0.34 & 0.43 & 0.55 & 0.59 & 0.55 & 0.65 & 0.46 \\
\hline $\mathrm{K}_{2} \mathrm{O}$ & 0.65 & 0.58 & 0.76 & 0.78 & 0.75 & 0.59 & 0.62 & 0.95 & 0.88 & 0.75 & 0.67 & 0.76 & 0.88 & 1.25 & 0.75 & 0.70 \\
\hline $\mathrm{Na}_{2} \mathrm{O}$ & 14.46 & 9.60 & 15.51 & 16.59 & 15.71 & 8.03 & 12.92 & 15.54 & 13.62 & 13.39 & 12.73 & 12.15 & 17.67 & 8.42 & 14.25 & 17.27 \\
\hline $\mathrm{P}_{2} \mathrm{O}_{5}$ & 0.15 & 0.12 & 0.10 & 0.17 & 0.17 & 0.10 & 0.11 & 0.12 & 0.15 & 0.10 & 0.10 & 0.09 & 0.12 & 0.28 & 0.14 & 0.11 \\
\hline $\mathrm{Cl}$ & 0.42 & 0.38 & 0.72 & 0.92 & 0.72 & 0.39 & 0.58 & 0.98 & 0.65 & 0.70 & 0.45 & 0.56 & 0.96 & 1.51 & 0.49 & 1.24 \\
\hline Total & 99.47 & 97.77 & 97.94 & 99.12 & 98.75 & 99.17 & 101.37 & 99.88 & 98.43 & 98.58 & 99.31 & 99.25 & 98.57 & 92.42 & 99.29 & 99.63 \\
\hline
\end{tabular}

n.d. not determined 
Fragment 103 displays a clearly different composition with 67-71\% for $\mathrm{SiO}_{2}, 1.7-2.7$ for $\mathrm{Al}_{2} \mathrm{O}_{3}, 8.1-10.3 \%$ for $\mathrm{CaO}$, 8.7-13.0\% for $\mathrm{K}_{2} \mathrm{O}$ and $7.9-9.6 \%$ for $\mathrm{Na}_{2} \mathrm{O}$ (Fig. 2a). In Fig. $2 b$, the average of all fragments except fragment 103 is compared with averages of Roman glass finds from various parts of the empire, showing a very good accordance and the extraordinary homogeneity of Roman glass. Fragment 103, on its part (column 12), is compared with different medieval K-rich glass compositions. Plotting all single analyses of all glass samples into the diagrams $\mathrm{Na}_{2} \mathrm{O}$ and $\mathrm{P}_{2} \mathrm{O}_{5}$ versus $\mathrm{K}_{2} \mathrm{O}$ (Fig. 3) demonstrates that the compositional range of the fragments covers the range of 45 Hellenistic and Roman glass samples, which were published by Brill (1999). An exception is again fragment 103, which clearly differs from all the others.

Ionic colouring agents

The colour of glass is in many cases caused by the addition of certain minor- or trace-elements, which in their ionic form are integrated into the network structure of the glass matrix. This kind of glass is primarily translucent, as can be seen in parts of the investigated samples. An additional introduction of microcrystals as opacifiers and further colouring agents leads to a formation of opaque glass and to a mixture of colouring effects. For the glass samples investigated, the following ionic colouring agents could be substantiated (see also Table 2):

Manganese: a purple colour is achieved by the addition of Mn, which therefore mainly occurs in its trivalent state when the atmosphere conditions in the glassfurnace are oxidizing (Sellner et al. 1979). Mn contents between 1.6 and 3.7 wt. $\% \mathrm{Mn}_{2} \mathrm{O}_{3}$ were detected in the respective parts of samples 2, 7, 33, 78, 83 and 102 . Depending on the content of $\mathrm{Mn}_{2} \mathrm{O}_{3}$, but also on the thickness of the glass, various shades of purple are observed, reaching from pink to violet and to dark purple with increasing $\mathrm{Mn}_{2} \mathrm{O}_{3}$-concentration: pink 1.7 wt. $\%$ in sample 2; violet 2.2 wt. $\%$ in sample 7; dark purple $3.6 \mathrm{wt} \%$ in sample 78 . It should be noted that these $\mathrm{Mn}_{2} \mathrm{O}_{3}$-values were calculated by stoichiometry from Mn contents, assuming the major part of Mn being trivalent as corroborated by the pink colours. The effective proportions of $\mathrm{MnO}-\mathrm{Mn}_{2} \mathrm{O}_{3}-\mathrm{MnO}_{2}$ in the samples can be only achieved by direct spectroscopic investigations of the Mn oxidation state, which was not carried out during the present study. As shown by recent studies, however, the tetravalent $\mathrm{Mn}$ is not really able to dissolve in a glass melt but resolves into trivalent and divalent Mn (Kurzmann 2003). Therefore it may not participate in a translucent glass as a colouring agent. In its crystallised form, $\mathrm{MnO}_{2}$ occurs in an exceptional high average content of 7.9 wt. $\%$ in the opaque dark part of sample 103 (see below).

Varying Mn-contents from the detection limit up to 1.5 wt. \% MnO are also measured in glass samples without purple, but different other colours. In these samples Mn should occur in its divalent state as a consequence of a more reducing furnace atmosphere. Thereby, Mn may operate as a decolourizing agent to neutralise the colouring effect of Fe (Sellner et al. 1979).

Cobalt: $\mathrm{Co}$ is responsible for a deep blue colour (Wedepohl 2003) as observed in the samples 33, 60, 87, 102 and 103. It was detected in concentrations of 0.06, 0.09, 0.11 and 0.08 wt. \% CoO, respectively, for the first four samples. These low trace element contents

\begin{tabular}{|c|c|c|c|c|c|c|c|c|c|c|c|c|c|c|c|c|c|}
\hline $\begin{array}{l}33 \\
\text { white }\end{array}$ & $\begin{array}{l}33 \\
\text { violet }\end{array}$ & $\begin{array}{l}33 \\
\text { red }\end{array}$ & $\begin{array}{l}33 \\
\text { yellow }\end{array}$ & $\begin{array}{l}33 \\
\text { blue }\end{array}$ & $\begin{array}{l}60 \\
\text { white }\end{array}$ & $\begin{array}{l}60 \\
\text { blue }\end{array}$ & $\begin{array}{l}78 \\
\text { white }\end{array}$ & $\begin{array}{l}78 \\
\text { yellow }\end{array}$ & $\begin{array}{l}78 \\
\text { violet }\end{array}$ & $\begin{array}{l}78 \\
\text { red }\end{array}$ & $\begin{array}{l}78 \\
\text { blue- } \\
\text { green }\end{array}$ & $\begin{array}{l}83 \\
\text { grey }\end{array}$ & $\begin{array}{l}83 \\
\text { blue } \\
\text { heart }\end{array}$ & $\begin{array}{l}83 \\
\text { blue } \\
\text { centre }\end{array}$ & $\begin{array}{l}83 \\
\text { blue } \\
\text { stalk }\end{array}$ & $\begin{array}{l}83 \\
\text { violet }\end{array}$ & $\begin{array}{l}83 \\
\text { yellow }\end{array}$ \\
\hline 61.82 & 64.49 & 57.25 & 51.05 & 65.35 & 67.55 & 69.31 & 67.11 & 66.40 & 64.82 & 58.60 & 68.21 & 65.06 & 64.09 & 64.88 & 66.82 & 66.57 & 65.72 \\
\hline 0.11 & 0.06 & 0.13 & 0.19 & 0.02 & 0.01 & n.d. & 0.08 & 0.05 & n.d. & 0.27 & 0.19 & 0.03 & 0.17 & 0.15 & 0.25 & 0.07 & 0.04 \\
\hline 6.22 & 0.31 & 1.00 & 1.42 & 0.82 & 4.82 & $<0,05$ & 3.19 & 1.20 & 0.46 & 0.26 & 3.11 & 0.24 & 0.33 & 0.39 & 0.57 & 0.29 & 0.62 \\
\hline 2.32 & 2.49 & 2.81 & 2.37 & 2.62 & 2.57 & 2.60 & 2.01 & 1.97 & 2.24 & 2.25 & 2.08 & 2.33 & 2.03 & 2.26 & 2.02 & 2.05 & 1.98 \\
\hline 5.85 & 0.84 & 10.71 & 23.15 & 2.06 & $<0.05$ & 0.07 & 0.05 & 5.52 & $<0.05$ & 6.88 & 0.12 & 0.08 & 1.25 & 1.51 & 2.88 & 0.20 & 5.68 \\
\hline$<0.05$ & 0.25 & 2.44 & 0.62 & 0.19 & n.d. & n.d. & n.d. & n.d. & n.d. & 1.55 & 1.95 & 0.33 & 1.36 & 1.71 & 1.70 & 0.36 & 0.27 \\
\hline n.d. & n.d. & n.d. & n.d. & 0.06 & n.d. & 0.09 & n.d. & n.d. & $<0.03$ & n.d. & n.d. & n.d. & n.d. & $<0.03$ & n.d. & n.d. & n.d. \\
\hline 0.39 & 0.67 & 1.37 & 2.75 & 1.49 & 0.37 & 0.98 & 0.48 & 0.66 & 0.85 & 1.61 & 0.46 & 0.70 & 0.77 & 0.75 & 0.58 & 0.51 & 0.51 \\
\hline 0.78 & 2.29 & 0.70 & 0.47 & 0.73 & 0.89 & 0.45 & $<0,05$ & 0.08 & 3.16 & 0.30 & 0.04 & 1.89 & 0.16 & 0.16 & 0.08 & 2.18 & 0.07 \\
\hline 6.74 & 7.79 & 7.30 & 5.27 & 7.55 & 7.55 & 7.07 & 6.83 & 5.90 & 7.15 & 8.81 & 5.66 & 9.39 & 9.89 & 8.81 & 6.69 & 7.74 & 7.36 \\
\hline 0.47 & 0.58 & 0.65 & 0.37 & 0.49 & 0.61 & 0.43 & 1.61 & 0.49 & 1.29 & 2.08 & 0.46 & 0.99 & 1.26 & 1.11 & 0.64 & 0.84 & 0.62 \\
\hline 0.71 & 0.91 & 0.88 & 0.72 & 0.85 & 0.73 & 0.71 & 0.54 & 0.47 & 0.96 & 1.70 & 0.51 & 0.63 & 1.15 & 1.10 & 0.53 & 0.73 & 0.67 \\
\hline 14.72 & 17.64 & 13.16 & 10.13 & 16.64 & 15.05 & 17.14 & 18.06 & 16.70 & 17.42 & 13.10 & 17.93 & 15.95 & 15.03 & 15.85 & 17.63 & 16.95 & 15.80 \\
\hline 0.08 & 0.16 & 0.12 & 0.07 & 0.12 & 0.17 & 0.08 & 0.07 & 0.06 & 0.26 & 0.69 & 0.08 & 0.12 & 0.37 & 0.34 & 0.09 & 0.19 & 0.05 \\
\hline 0.64 & 0.94 & 0.69 & 0.42 & 0.99 & 0.45 & 1.18 & 1.04 & 1.18 & 1.01 & 0.75 & 1.19 & 1.04 & 0.93 & 1.00 & 1.17 & 1.15 & 1.02 \\
\hline 100.84 & 99.41 & 99.19 & 99.00 & 99.97 & 100.75 & 100.11 & 101.07 & 100.67 & 99.62 & 98.84 & 101.99 & 98.75 & 98.76 & 100.01 & 101.64 & 99.81 & 100.38 \\
\hline
\end{tabular}


are well in the position to give this deep blue colour to the glass. A remarkably high value of $0.36 \mathrm{wt} . \% \mathrm{CoO}$ was measured in sample 103. The deep blue glass of samples 33 and 103 contains additional opacifiers $(\mathrm{Ca}$ antimonate, see below) which, however, does not really influence the colour.

Copper: $\mathrm{Cu}$ in its divalent state was used to produce a light blue colour in the translucent glass. The $\mathrm{CuO}$ contents in samples 2, 6, 83 and 93 range between 1.4 and $2.7 \mathrm{wt} . \%$. In all four samples, the translucent light blue colour was also used to evoke a very nice mixing effect by underlaying part of the blue matrix with yellow glass in spiral or radiant pattern (samples 2, 6), as tiny yellow tubes (sample 93) or in figurative forms (poppy flowers in sample 83: in this sample the blue glass is also mixed with yellow pigments). In the vicinity of the yellow parts, the light blue glass appears in various green to blue-green colours, depending on the thickness of the light blue overlayer (see Fig. 1).

In parts of the $\mathrm{Cu}$-induced blue matrix of sample $83, \mathrm{Ca}$ antimonates are used as an opacifier. In sample 78, the $\mathrm{Cu}$ induced light blue is changed to an opaque cyan by addition of Ca-antimonates. The opaque green colours in samples 7 and 103 are caused by a combination of $\mathrm{CuO}, \mathrm{PbO}$ and microcrystals ( $\mathrm{Ca}$ antimonate in sample 7 , cassiterite in sample 103, see below). The samples contain 4.9 and 3.1 wt. $\% \mathrm{CuO}$ and 10.3 and 24.4 wt.\% $\mathrm{PbO}$, respectively. It is well known that $\mathrm{Cu}$-induced blue glass with an addition of considerable amounts of PbO turns to green (Weyl 1953; Wedepohl 2003).

Iron: $\mathrm{Fe}$ in its trivalent state can be responsible for the yellow-brown colour of glass (Scholze 1988;
Kurzmann 2003). In the translucent yellow-brown parts of fragments 2 and 29, no colouring agents except $\mathrm{Fe}$ were detected. $\mathrm{Fe}_{2} \mathrm{O}_{3}$ contents of 0.39 and 0.29 wt. \%, respectively, are therefore assumed to cause this colour. Comparable or even higher $\mathrm{Fe}_{2} \mathrm{O}_{3}$ contents are detected in all the other coloured glass samples, however, normally combined with decolourizing Mn or combined with other, more intensive colouring agents. Within the yellow-brown glass of samples 2 and 29, the $\mathrm{MnO}$ contents are exceptionally low, i.e. close to or even below the detection limit of the microprobe, and other colouring agents are missing. Therefore $\mathrm{Fe}^{3+}$ can evolve its typical yellow-brown tinge in the translucent glass. In the vicinity of opaque white ornaments, the brown turns to a honey-coloured yellow.

Microcrystals as opacifier and colourants

Looking at the backscattered electron images of the opaque glass parts under the electron microprobe, it becomes obvious that this kind of glass is intensively interspersed by innumerable tiny crystallites, which play the role of opacifying and colouring agents (Fig. 4). These are either primarily supplied as crystal powder to the melt, or they crystallise and grow inside the glass melt during the cooling procedure, fed by certain major and/or trace elements of the melt (Mass et al. 2002; Shortland 2002). For the first case, an ideal moment for the addition of the crystal powder to the melt has to be adjusted; this is done when the melt is cool enough not to dissolve the crystals, but still viscous enough to allow for mixing the crystals and the melt (Shortland 2002). For the second case, depending on the kind of crystals, a special heat-treatment of the melt during

Table 1 (continued)

\begin{tabular}{|c|c|c|c|c|c|c|c|c|c|c|c|c|c|c|c|c|c|}
\hline $\begin{array}{l}\text { Fragment } \\
\text { (wt.\%) }\end{array}$ & $\begin{array}{l}83 \\
\text { yellow } \\
\text { stalk }\end{array}$ & $\begin{array}{l}83 \\
\text { yellow }\end{array}$ & $\begin{array}{l}83 \\
\text { white }\end{array}$ & $\begin{array}{l}87 \\
\text { white }\end{array}$ & $\begin{array}{l}87 \\
\text { yellow }\end{array}$ & $\begin{array}{l}87 \\
\text { blue }\end{array}$ & $\begin{array}{l}93 \\
\text { yellow }\end{array}$ & $\begin{array}{l}93 \\
\text { blue- } \\
\text { green }\end{array}$ & $\begin{array}{l}102 \\
\text { yellow }\end{array}$ & $\begin{array}{l}102 \\
\text { white }\end{array}$ & $\begin{array}{l}102 \\
\text { blue }\end{array}$ & $\begin{array}{l}102 \\
\text { violet }\end{array}$ & $\begin{array}{l}103 \\
\text { white }\end{array}$ & $\begin{array}{l}103 \\
\text { dark }\end{array}$ & $\begin{array}{l}103 \\
\text { red }\end{array}$ & $\begin{array}{l}103 \\
\text { yellow- } \\
\text { green }\end{array}$ & $\begin{array}{l}103 \\
\text { blue }\end{array}$ \\
\hline $\mathrm{SiO}_{2}$ & 67.94 & 68.63 & 68.65 & 59.20 & 60.88 & 69.67 & 63.16 & 67.84 & 46.74 & 64.74 & 65.87 & 64.61 & 52.71 & 45.53 & 41.37 & 40.41 & 57.39 \\
\hline $\mathrm{SnO}_{2}$ & 0.09 & 0.00 & 0.04 & 0.25 & 0.14 & n.d. & 0.04 & 0.09 & 0.07 & 0.06 & n.d. & n.d. & 0.11 & 2.89 & 0.80 & 10.20 & n.d. \\
\hline $\mathrm{Sb}_{2} \mathrm{O}_{3}$ & 0.70 & 1.02 & 0.67 & 9.40 & 2.10 & 0.76 & 0.86 & 0.29 & 2.32 & 5.58 & 0.03 & $<0.05$ & 7.81 & 0.00 & 1.43 & 0.35 & 4.67 \\
\hline $\mathrm{Al}_{2} \mathrm{O}_{3}$ & 2.27 & 2.27 & 2.17 & 2.19 & 2.34 & 2.16 & 1.99 & 2.10 & 1.87 & 2.22 & 2.26 & 2.16 & 1.74 & 1.27 & 1.67 & 1.55 & 1.40 \\
\hline $\mathrm{PbO}$ & 3.78 & 0.01 & 0.70 & 8.18 & 10.49 & n.d. & 11.38 & 0.08 & 30.71 & 0.04 & $<0.05$ & 0.10 & 7.89 & 15.44 & 25.95 & 24.42 & 2.10 \\
\hline $\mathrm{CuO}$ & 0.20 & $<0.05$ & 0.08 & n.d. & n.d. & n.d. & n.d. & 1.69 & n.d. & n.d. & n.d. & n.d. & n.d. & n.d. & 2.27 & 3.07 & n.d. \\
\hline $\mathrm{CoO}$ & n.d. & n.d. & n.d. & n.d. & n.d. & 0.11 & n.d. & n.d. & n.d. & n.d. & 0.08 & $<0.03$ & n.d. & n.d. & n.d. & n.d. & 0.36 \\
\hline $\mathrm{FeO}$ & 0.60 & 0.48 & 0.54 & 0.66 & 1.26 & 1.37 & 0.51 & 0.92 & 1.44 & 0.41 & 1.19 & 0.40 & 0.85 & 0.74 & 1.99 & 0.58 & 0.76 \\
\hline $\mathrm{MnO}$ & 0.04 & 0.00 & 0.14 & 1.15 & 1.45 & 1.36 & 0.02 & 0.10 & 0.40 & 0.60 & 1.07 & 2.19 & 0.27 & 6.49 & 0.96 & 0.55 & 0.31 \\
\hline $\mathrm{CaO}$ & 6.94 & 7.70 & 7.79 & 5.24 & 4.93 & 5.27 & 4.90 & 6.16 & 4.93 & 8.95 & 9.28 & 9.53 & 6.83 & 6.66 & 6.35 & 4.63 & 8.30 \\
\hline $\mathrm{MgO}$ & 0.64 & 1.30 & 0.80 & 0.75 & 0.79 & 0.82 & 0.41 & 1.12 & 0.33 & 0.55 & 0.64 & 0.64 & 1.03 & 0.70 & 0.90 & 0.93 & 0.97 \\
\hline $\mathrm{K}_{2} \mathrm{O}$ & 0.48 & 0.55 & 0.57 & 0.77 & 0.93 & 0.99 & 0.68 & 1.00 & 0.64 & 0.75 & 0.62 & 0.72 & 10.11 & 7.79 & 6.84 & 4.93 & 10.02 \\
\hline $\mathrm{Na}_{2} \mathrm{O}$ & 16.64 & 17.32 & 16.81 & 12.15 & 12.06 & 16.39 & 14.63 & 17.71 & 8.09 & 15.76 & 16.45 & 16.91 & 6.11 & 6.49 & 5.38 & 5.42 & 7.40 \\
\hline $\mathrm{P}_{2} \mathrm{O}_{5}$ & 0.04 & $<0.05$ & 0.08 & 0.17 & 0.21 & 0.32 & 0.04 & 0.33 & 0.13 & 0.19 & 0.08 & 0.19 & 1.22 & 1.45 & 1.00 & 0.63 & 1.49 \\
\hline $\mathrm{Cl}$ & 1.05 & 1.04 & 1.03 & 0.52 & 0.79 & 1.03 & 1.10 & 1.22 & 0.31 & 0.36 & 1.27 & 0.98 & 0.30 & 0.73 & 0.38 & 0.29 & 0.38 \\
\hline Total & 101.36 & 100.31 & 100.05 & 100.61 & 98.33 & 100.25 & 99.73 & 100.65 & 97.98 & 100.21 & 98.83 & 98.44 & 97.00 & 96.18 & 97.30 & 97.96 & 95.55 \\
\hline
\end{tabular}



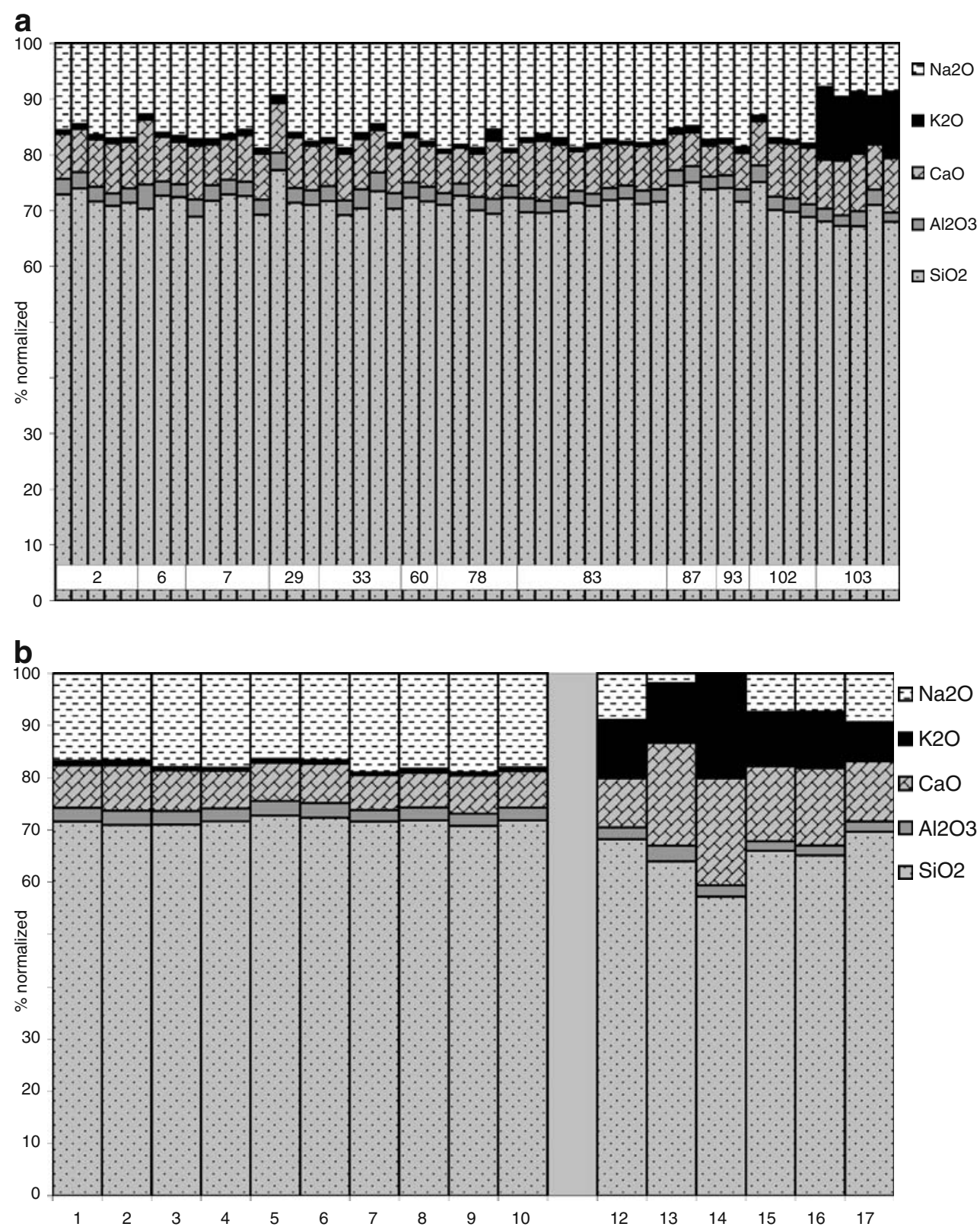

Fig. 2 a Basic glass composition including the oxides of $\mathrm{Si}, \mathrm{Al}, \mathrm{Ca}$, $\mathrm{K}, \mathrm{Na}$ of all fragments, after subtracting the additional elements from the analysis and normalisation to $100 \%$. This procedure is carried out to oppress the influence of the very variable quantities of additional elements to the basic glass receipt, thus making the basic receipts comparable with glass analyses from other occurrences, i.e. with common Roman glass. b Comparison of the investigated fragments with glass compositions from various Roman and Medieval provenances: 1 average of all the investigated fragments, but without fragment 103. 2 Average of 11 fragments of Roman cameo-glass of the Martin von Wagner Museum Würzburg (Weiß and Schüssler 2000). 3 Average of five Roman cameo-glass vases exposed at the British Museum London (Bimson and Freestone 1988). 4 Average of 36 Roman glass samples from Italy, Switzerland and Yugoslavia, firstthird century AD (Braun 1983). 5 Average of 59 Roman glass samples from Poitier, second-third century AD (Velde and Gendron 1980).
6 Average of 48 Roman glass samples from Rouen, first-fourth century AD (Velde and Sennequier 1985). 7 Average of 78 Roman glasses from Cologne, first-fourth century AD (Rottländer 1990). 8 Average of 43 Roman glasses from Cosa near Rome, second century BC-third century AD (Brill 1999). 9 Average of 20 Roman glass samples from Aquileia, first-fifth century AD (Verità and Toninato 1990). 10 Average of 781 Roman glass samples from various parts of the Roman Empire (Wedepohl 2003). 12 Fragment 103. 13 Average of 40 wood ash glasses of the Early Middleages from Germany, Norway, France and England (Wedepohl 2003). 14 Average of 41 wood ash glasses of the High and Late Middleages from Germany (Wedepohl 2003). 15 and 16 Knob beakers $84 / 9$ and $84 / 27$ b, fifteenth century AD, glassworks Nassachtal, Germany (Schüssler and Lang 2002). 17 Knob beaker, thirteenth century AD, Braunschweig (Bruckschen 2000) 

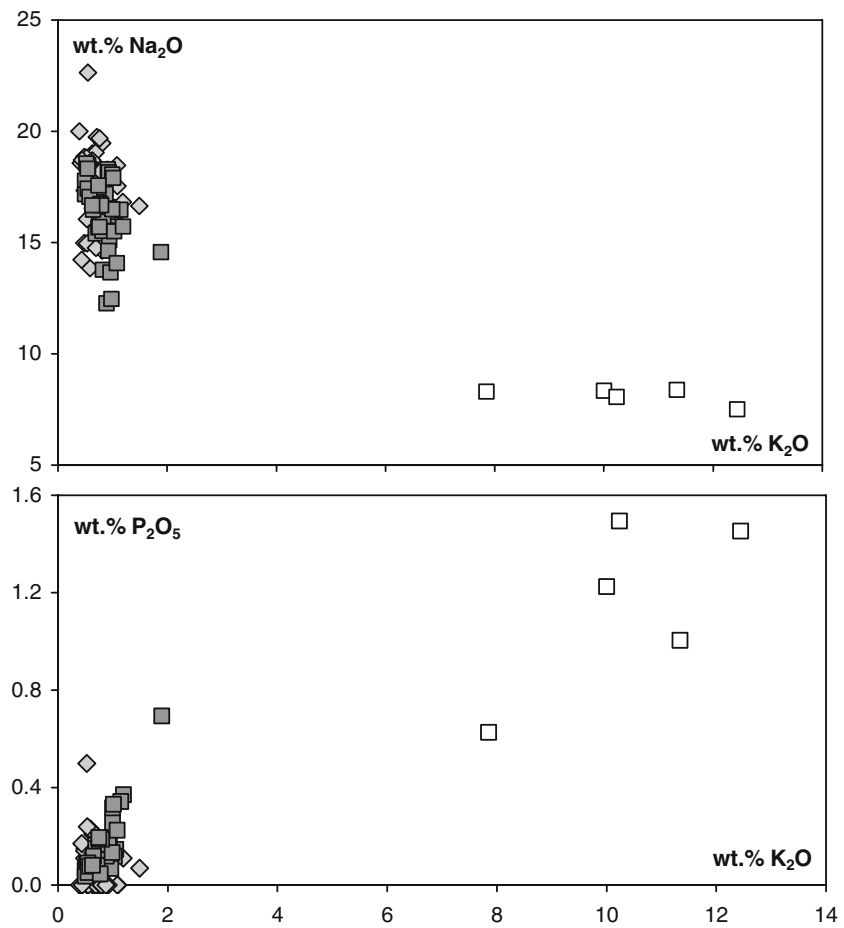

Fig. 3 Eleven fragments (filled squares) and fragment 103 (open squares) in the diagrams $\mathrm{Na}_{2} \mathrm{O}$ and $\mathrm{P}_{2} \mathrm{O}_{5}$ versus $\mathrm{K}_{2} \mathrm{O}$, compared to 45 Hellenistic and Roman glasses (diamonds) (Brill 1999)

the cooling procedure may be necessary to initiate the formation of seed crystals and to allow for crystal growing, as described for example by Harding et al. (1989) for red colourants. The size of the pigment crystals normally ranges between less than $1 \mu \mathrm{m}$ up to about 3 or $4 \mu \mathrm{m}$. Occasionally, several crystals form small agglomerates of about $10 \mu \mathrm{m}$. The number of crystals per volume differs strongly from colourant to colourant and from sample to sample.

To identify the tiny pigments, the spatial resolution of an electron microprobe is not sufficient in many cases. Nondestructive X-ray powder diffraction could be an appropriate method, but in the case of the mosaic glass, a high spatial resolution of the X-ray beam is essential, but not yet standard for most of the instruments. Alternatively, Raman microspectroscopy has turned out as a powerful method, which works non-destructively, fast, with high spatial resolution, and which allows for highly variable sample sizes (Welter et al. 2007). For the studied glass fragments, the following colourants and opacifiers have been characterised:

Calcium antimonate is typical for all the opaque white glass samples. Thereby a hexagonal $\mathrm{CaSb}_{2} \mathrm{O}_{6}$ can be distinguished from an orthorhombic $\mathrm{Ca}_{2} \mathrm{Sb}_{2} \mathrm{O}_{7}$. The lack of a yet published $\mathrm{Ca}_{2} \mathrm{Sb}_{2} \mathrm{O}_{7}$ spectrum led us to synthesise both kinds of calcium antimonate to produce suitable reference spectra. $\mathrm{CaCO}_{3}$ and $\mathrm{Sb}_{2} \mathrm{O}_{3}$ in a 1:1 molar ratio were mixed in a mortar and then fired at $1,100^{\circ} \mathrm{C}$ for $10 \mathrm{~h}$ in a muffle furnace to receive a $\mathrm{CaSb}_{2} \mathrm{O}_{6}$-dominated colourless powder. A molar ratio of 2:1 at similar conditions yielded a $\mathrm{Ca}_{2} \mathrm{Sb}_{2} \mathrm{O}_{7^{-}}$ dominated colourless powder. Repeated experiments consistently resulted in mixtures of both calcium antimonates, with respective predominance of one type, however. The results were verified by X-ray powder-diffractometry before taking the Raman reference spectra. As presented in Fig. 5a, hexagonal $\mathrm{CaSb}_{2} \mathrm{O}_{6}$ is characterised by Raman bands at 234, 323, 517 and $666 \mathrm{~cm}^{-1}$, in good agreement with published values (Husson et al. 1984). Orthorombic $\mathrm{Ca}_{2} \mathrm{Sb}_{2} \mathrm{O}_{7}$ displays characteristic Raman bands at 318 , 367, 472, 624, 781 and $821 \mathrm{~cm}^{-1}$ (Fig. 5b). The white glass of the investigated fragments is typically coloured by the orthorhombic $\mathrm{Ca}_{2} \mathrm{Sb}_{2} \mathrm{O}_{7}$, i.e. in samples 7,29 , 33, 60, 78, 83, 87, 102 and 103. Figure 5d shows a Raman spectrum typical for the white glass, taken from sample 83. As an exception, white glass of sample 2 contains both $\mathrm{CaSb}_{2} \mathrm{O}_{6}$ (Fig. 5c) and $\mathrm{Ca}_{2} \mathrm{Sb}_{2} \mathrm{O}_{7}$ (similar to Fig. 5d).

Calcium antimonates are also used as opacifiers for other colours than white, but furthermore as colourant to produce mixed colours. In samples 33 and 103 the Co-induced blue glass contains $\mathrm{Ca}_{2} \mathrm{Sb}_{2} \mathrm{O}_{7}$ only as an opacifier. In sample 83, the $\mathrm{Cu}$-blue partly occurs opaque because of $\mathrm{Ca}_{2} \mathrm{Sb}_{2} \mathrm{O}_{7}$ together with $\mathrm{CaSb}_{2} \mathrm{O}_{6}$. In sample 78, $\mathrm{Cu}$-induced light blue is turned to an opaque cyan by the addition of $\mathrm{CaSb}_{2} \mathrm{O}_{6}$. In sample 7, the green colour of the matrix glass is produced by $\mathrm{Cu}+\mathrm{Pb}$ in combination with $\mathrm{Ca}_{2} \mathrm{Sb}_{2} \mathrm{O}_{7}$.

Lead antimonate $\mathrm{Pb}_{2} \mathrm{Sb}_{2} \mathrm{O}_{7}$, also called "naples yellow", is the colouring and opacifying agent in all the yellow glass parts investigated, i.e. in samples 2, 6, 7, $33,78,83,87,93$ and 102. A representative spectrum of fragment 87 is shown in Fig. 6, with characteristic Raman bands at 142, 332, 450 and $506 \mathrm{~cm}^{-1}$ (Clark et al. 1995). Interestingly, lead antimonate was also detected in a blue-green part in the context of the poppy flowers of sample 83. Most probably, the $\mathrm{Cu}$ induced light blue translucent matrix glass is doped by a low amount of yellow lead antimonate to produce a blue-green mixed colour (Fig. 4).

Cuprite $\mathrm{Cu}_{2} \mathrm{O}$ could be identified as the colouring agent in all the red opaque glass samples, although the crystallites with diametres between 0.5 and $1 \mu \mathrm{m}$ are clearly smaller, compared to the other crystal types (Fig. 4 (7 red)). The characteristic Raman bands are at 154 and $216 \mathrm{~cm}^{-1}$ (Bouchard and Smith 2003), as shown in Fig. 7a for the red glass of fragment 103. The very irregular background of the cuprite spectra is a 
Table 2 Compilation of colouring and opacifying agents for all differently coloured glass parts of all fragments

\begin{tabular}{|c|c|c|c|}
\hline & Ionic colouring agent & Colouring crystals & Opacifying crystals \\
\hline \multicolumn{4}{|l|}{ Fragment 2} \\
\hline White & & $\mathrm{CaSb}_{2} \mathrm{O}_{6}+\mathrm{Ca}_{2} \mathrm{Sb}_{2} \mathrm{O}_{7}$ & $\mathrm{CaSb}_{2} \mathrm{O}_{6}+\mathrm{Ca}_{2} \mathrm{Sb}_{2} \mathrm{O}_{7}$ \\
\hline Yellow & & $\mathrm{Pb}_{2} \mathrm{Sb}_{2} \mathrm{O}_{7}$ & $\mathrm{~Pb}_{2} \mathrm{Sb}_{2} \mathrm{O}_{7}$ \\
\hline Violet & $\mathrm{Mn}^{3+}$ & & \\
\hline Blue & $\mathrm{Cu}^{2+}$ & & \\
\hline Brown & $\mathrm{Fe}^{3+}$ & & \\
\hline Yellow brown & Translucent brown overlaying opaque white & & \\
\hline Green & Translucent blue overlaying opaque yellow & & \\
\hline \multicolumn{4}{|l|}{ Fragment 6} \\
\hline White & & $\mathrm{Ca}$ antimonate & $\mathrm{Ca}$ antimonate \\
\hline Yellow & & $\mathrm{Pb}_{2} \mathrm{Sb}_{2} \mathrm{O}_{7}$ & $\mathrm{~Pb}_{2} \mathrm{Sb}_{2} \mathrm{O}_{7}$ \\
\hline Blue & $\mathrm{Cu}^{2+}$ & & \\
\hline Green & Translucent blue overlaying opaque yellow & & \\
\hline \multicolumn{4}{|l|}{ Fragment 7} \\
\hline White & & $\mathrm{Ca}_{2} \mathrm{Sb}_{2} \mathrm{O}_{7}$ & $\mathrm{Ca}_{2} \mathrm{Sb}_{2} \mathrm{O}_{7}$ \\
\hline Yellow & & $\mathrm{Pb}_{2} \mathrm{Sb}_{2} \mathrm{O}_{7}$ & $\mathrm{~Pb}_{2} \mathrm{Sb}_{2} \mathrm{O}_{7}$ \\
\hline Red & & $\mathrm{Cu}_{2} \mathrm{O}$ & $\mathrm{Cu}_{2} \mathrm{O}$ \\
\hline Violet & $\mathrm{Mn}^{3+}$ & & \\
\hline Green & $\mathrm{Cu}^{2+}+\mathrm{Pb}$ & & $\mathrm{Ca}_{2} \mathrm{Sb}_{2} \mathrm{O}_{7}$ \\
\hline \multicolumn{4}{|l|}{ Fragment 29} \\
\hline White & & $\mathrm{Ca}_{2} \mathrm{Sb}_{2} \mathrm{O}_{7}$ & $\mathrm{Ca}_{2} \mathrm{Sb}_{2} \mathrm{O}_{7}$ \\
\hline Brown & $\mathrm{Fe}^{3+}$ & & \\
\hline Yellow brown & Translucent brown overlaying opaque white & & \\
\hline \multicolumn{4}{|l|}{ Fragment 33} \\
\hline White & & $\mathrm{Ca}_{2} \mathrm{Sb}_{2} \mathrm{O}_{7}$ & $\mathrm{Ca}_{2} \mathrm{Sb}_{2} \mathrm{O}_{7}$ \\
\hline Yellow & & $\mathrm{Pb}_{2} \mathrm{Sb}_{2} \mathrm{O}_{7}$ & $\mathrm{~Pb}_{2} \mathrm{Sb}_{2} \mathrm{O}_{7}$ \\
\hline Red & & $\mathrm{Cu}_{2} \mathrm{O}$ & $\mathrm{Cu}_{2} \mathrm{O}$ \\
\hline Violet & $\mathrm{Mn}^{3+}$ & & \\
\hline Blue & Co & & $\mathrm{Ca}_{2} \mathrm{Sb}_{2} \mathrm{O}_{7}$ \\
\hline \multicolumn{4}{|l|}{ Fragment 60} \\
\hline White & & $\mathrm{Ca}_{2} \mathrm{Sb}_{2} \mathrm{O}_{7}$ & $\mathrm{Ca}_{2} \mathrm{Sb}_{2} \mathrm{O}_{7}$ \\
\hline Blue & Co & & \\
\hline \multicolumn{4}{|l|}{ Fragment 78} \\
\hline White & & $\mathrm{Ca}_{2} \mathrm{Sb}_{2} \mathrm{O}_{7}$ & $\mathrm{Ca}_{2} \mathrm{Sb}_{2} \mathrm{O}_{7}$ \\
\hline Yellow & & $\mathrm{Pb}_{2} \mathrm{Sb}_{2} \mathrm{O}_{7}$ & $\mathrm{~Pb}_{2} \mathrm{Sb}_{2} \mathrm{O}_{7}$ \\
\hline Red & & $\mathrm{Cu}_{2} \mathrm{O}$ & $\mathrm{Cu}_{2} \mathrm{O}$ \\
\hline Violet & $\mathrm{Mn}^{3+}$ & & \\
\hline Cyan & $\mathrm{Cu}^{2+}$ & $\mathrm{CaSb}_{2} \mathrm{O}_{6}$ & $\mathrm{CaSb}_{2} \mathrm{O}_{6}$ \\
\hline \multicolumn{4}{|l|}{ Fragment 83} \\
\hline White & & $\mathrm{Ca}_{2} \mathrm{Sb}_{2} \mathrm{O}_{7}$ & $\mathrm{Ca}_{2} \mathrm{Sb}_{2} \mathrm{O}_{7}$ \\
\hline Yellow & & $\mathrm{Pb}_{2} \mathrm{Sb}_{2} \mathrm{O}_{7}$ & $\mathrm{~Pb}_{2} \mathrm{Sb}_{2} \mathrm{O}_{7}$ \\
\hline Violet & $\mathrm{Mn}^{3+}$ & 10200207 & $U_{2}-\mathrm{NO}_{2} \mathrm{O}$ \\
\hline Blue & $\mathrm{Cu}^{2+}$ & & $\pm \mathrm{CaSb}_{2} \mathrm{O}_{6} \pm \mathrm{Ca}_{2} \mathrm{Sb}_{2} \mathrm{O}_{7}$ \\
\hline Blue-green & $\mathrm{Cu}^{2+}$ & $\mathrm{Pb}_{2} \mathrm{Sb}_{2} \mathrm{O}_{7}$ & $\mathrm{~Pb}_{2} \mathrm{Sb}_{2} \mathrm{O}_{7}$ \\
\hline \multicolumn{4}{|l|}{ Fragment 87} \\
\hline White & & $\mathrm{Ca}_{2} \mathrm{Sb}_{2} \mathrm{O}_{7}$ & $\mathrm{Ca}_{2} \mathrm{Sb}_{2} \mathrm{O}_{7}$ \\
\hline Yellow & & $\mathrm{Pb}_{2} \mathrm{Sb}_{2} \mathrm{O}_{7}$ & $\mathrm{~Pb}_{2} \mathrm{Sb}_{2} \mathrm{O}_{7}$ \\
\hline Blue & Co & & \\
\hline \multicolumn{4}{|l|}{ Fragment 93} \\
\hline Yellow & & $\mathrm{Pb}_{2} \mathrm{Sb}_{2} \mathrm{O}_{7}$ & $\mathrm{~Pb}_{2} \mathrm{Sb}_{2} \mathrm{O}_{7}$ \\
\hline Blue & $\mathrm{Cu}^{2+}$ & & \\
\hline Green & Translucent blue overlaying opaque yellow & & \\
\hline \multicolumn{4}{|l|}{ Fragment 102} \\
\hline White & & $\mathrm{Ca}_{2} \mathrm{Sb}_{2} \mathrm{O}_{7}$ & $\mathrm{Ca}_{2} \mathrm{Sb}_{2} \mathrm{O}_{7}$ \\
\hline Yellow & & $\mathrm{Pb}_{2} \mathrm{Sb}_{2} \mathrm{O}_{7}$ & $\mathrm{~Pb}_{2} \mathrm{Sb}_{2} \mathrm{O}_{7}$ \\
\hline Violet & $\mathrm{Mn}^{3+}$ & & \\
\hline Blue & Co & & \\
\hline \multicolumn{4}{|l|}{ Fragment 103} \\
\hline White & & $\mathrm{Ca}_{2} \mathrm{Sb}_{2} \mathrm{O}_{7}$ & $\mathrm{Ca}_{2} \mathrm{Sb}_{2} \mathrm{O}_{7}$ \\
\hline Red & & $\mathrm{Cu}_{2} \mathrm{O}$ & $\mathrm{Cu}_{2} \mathrm{O}$ \\
\hline Blue & Co & & $\mathrm{Ca}_{2} \mathrm{Sb}_{2} \mathrm{O}_{7}$ \\
\hline Dark & $\mathrm{Mn}^{3+}$ & $\mathrm{MnO}_{2}$ & $\mathrm{MnO}_{2}$ \\
\hline Green yellow & $\mathrm{Cu}^{2+}+\mathrm{Pb}$ & $\mathrm{SnO}_{2}$ & $\mathrm{SnO}_{2}$ \\
\hline
\end{tabular}

Fragment 6: Ca antimonate was substantiated by electron microprobe, but not by Raman microspectroscopy 

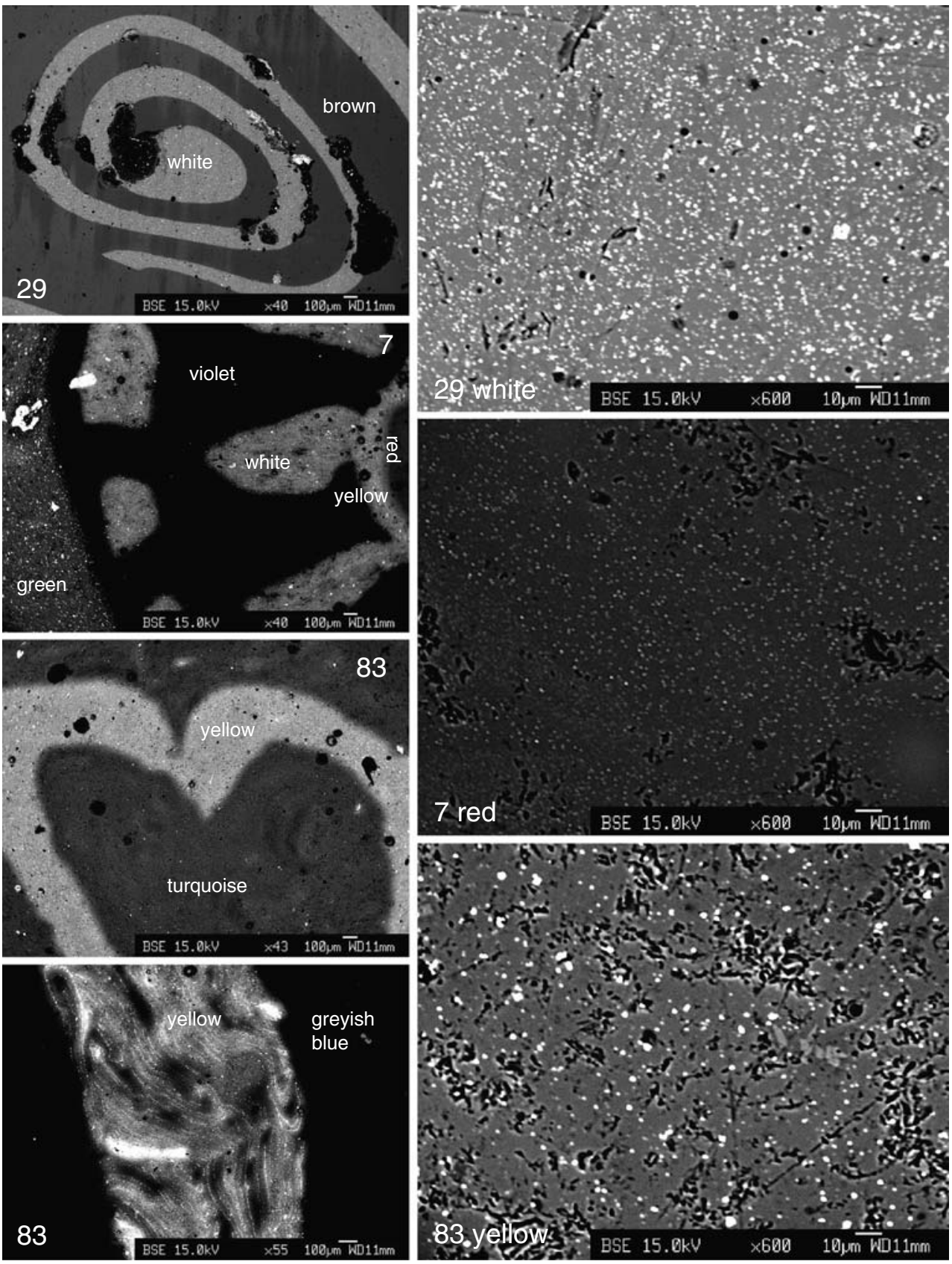

Fig. 4 View of selected sample parts under the electron microscope in backscattered electron (bse) mode: a white helix of fragment 29 in a brown glass matrix; the helix appears white also in the bse image because of its high content of calcium-antimonate crystals which are shown on the right side in a higher magnification. The brown glass appears dark because of its lower average atomic number and the missing of any crystals. A detail of fragment 7 shows the red core of a flower surrounded by a yellow rim (with lead-antimonate as colouring agent) and white leaves (with calcium-antimonate as colouring agent), the latter embedded in a $\mathrm{Mn}^{3+}$-violet glass matrix without any crystals; at the left side of the picture part of the green opaque glass interstitially occurring between the flowers (with $\mathrm{Pb}$ and $\mathrm{Cu}$ as colouring agent and calcium-antimonate as opacifier). The red core is coloured by very finegrained cuprite crystals which are shown in larger magnification at the right side. Fragment 83 with a heart-like yellow detail of a poppy flower coloured by lead-antimonate crystals as shown in larger magnification at the left (note that all three high magnification pictures are displayed at the same magnification). The torquoise is produced by a $\mathrm{Cu}$-blue translucent glass, covering the yellow opaque glass. The lowermost image of fragment 83 shows the detail of a yellow stipe of a poppy flower, coloured by lead antimonates, but inhomogeneously intermixed with the greyish blue matrix glass to receive a somewhat diffuse appearance 

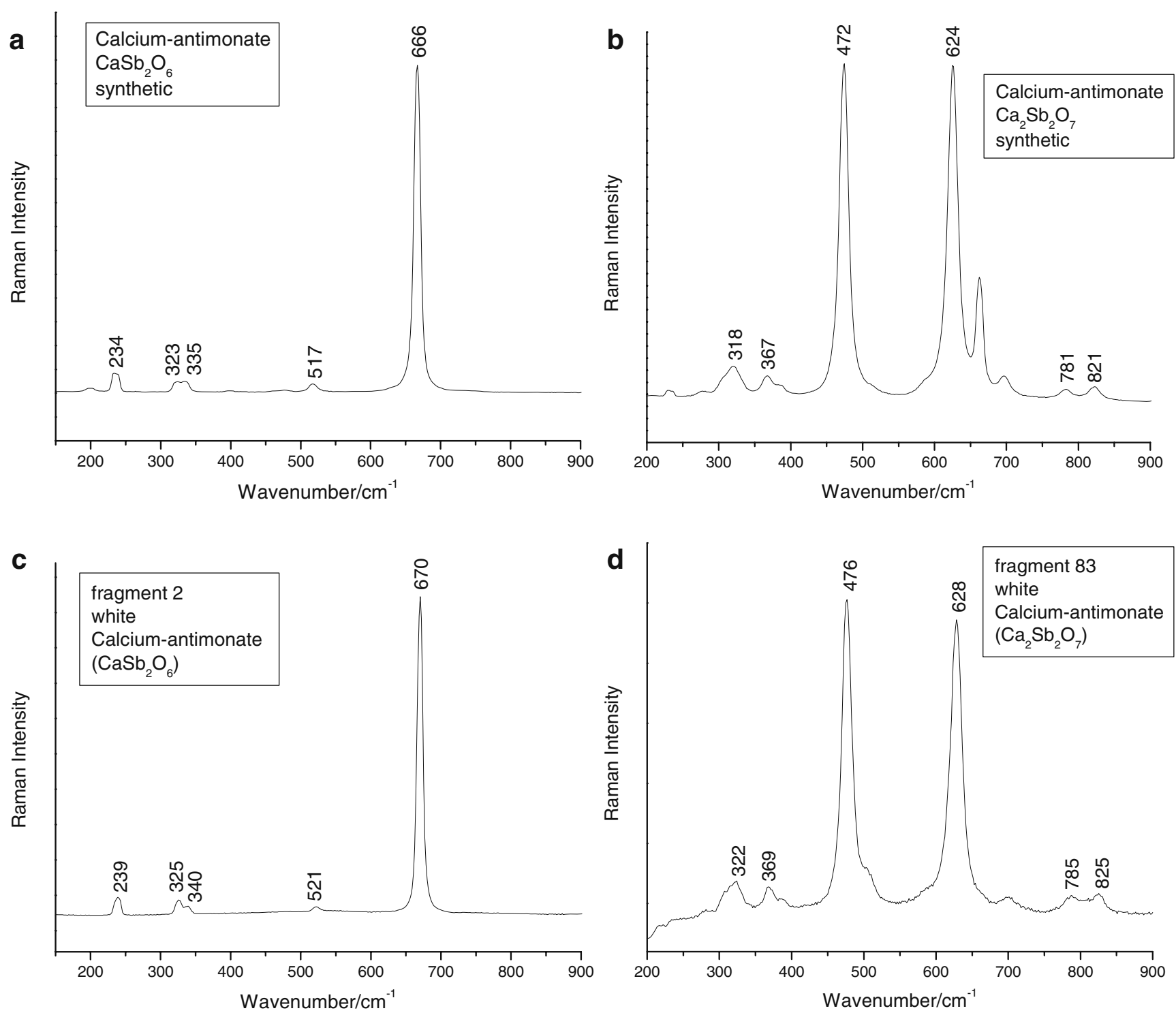

Fig. 5 Raman-spectra of calcium antimonates; a synthetic $\mathrm{CaSb}_{2} \mathrm{O}_{6}$, b synthetic $\mathrm{Ca}_{2} \mathrm{Sb}_{2} \mathrm{O}_{7}, \mathbf{c} \mathrm{CaSb}_{2} \mathrm{O}_{6}$ as a white-colouring agent in fragment 2 and $\mathbf{d ~} \mathrm{Ca}_{2} \mathrm{Sb}_{2} \mathrm{O}_{7}$ as a white-colouring agent in fragment 83

result of indistinct signals from the surrounding glass matrix in consequence of very small grain sizes of the cuprite and of fluorescence effects.

The formation of cuprite from the glass melt requires accurate calibration of the atmosphere in the melting furnace. An oxidizing atmosphere produces divalent $\mathrm{Cu}$ and therefore a light blue translucent glass. Strongly reducing atmosphere leads to the formation of elementary $\mathrm{Cu}$ crystals. Only under a slightly reducing atmosphere, the monovalent $\mathrm{Cu}$ occurs to form $\mathrm{Cu}_{2} \mathrm{O}$ (Freestone 1987; Brill and Cahill 1988). The size and the amount of the cuprite crystals determine the shade of the red colour. An increasing number of constantly small crystallites and an increasing homogeneity of the cuprite distribution make the colour of the glass more intensive and homogeneous. This is influenced by the addition of lead to the glass melt (Freestone 1987; Wedepohl 2003). Therefore, most of the red opaque glasses described in literature and all of the red samples presented here contain certain amounts of lead. An increase of the crystal number and the homogeneity of their distribution correlating to the concentration of lead was also confirmed by backscattered images of the samples 7 and 78 (7-10 wt.\% PbO) compared with sample 103 (26 wt.\% $\mathrm{PbO})$. In the Raman spectra, this lead may be displayed by a very typical band at $984 \mathrm{~cm}^{-1}$ (Colomban et al. 2003), as shown in Fig. 7b, indicating that the glass matrix is formed by a network of two-dimensional chains of $\mathrm{SiO}_{4}$ tetrahedra with mainly two non-binding oxygen atoms, in contrast to Na- and K-dominated glass with mostly one non-binding 


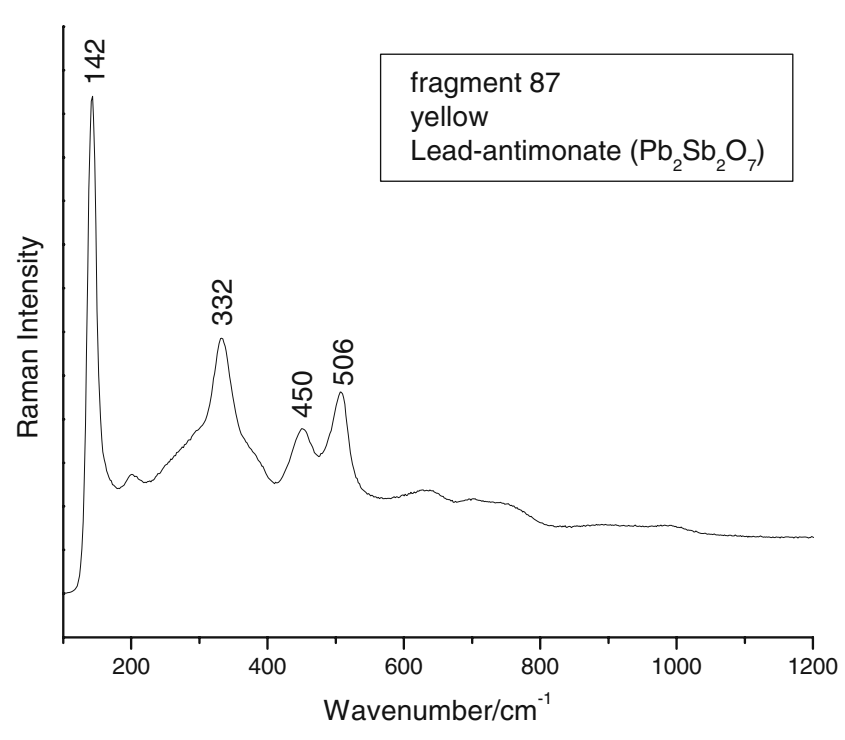

Fig. 6 Raman-spectrum of lead antimonate as a yellow-colouring agent in fragment 87

oxygen atom and a sheet-like network (Welter et al. 2007). The growth of cuprite crystals is of course also depending on temperature treatment (Henderson 1985).

Cassiterite $\mathrm{SnO}_{2}$ serves as an opacifier only in the green part of sample 103, which obtains the green colour by a mixture of $\mathrm{Cu}$ and $\mathrm{Pb}$. Within the spectrum, the typical Raman bands are at 474, 633 and $775 \mathrm{~cm}^{-1}$ (Fig. 8) (Bouchard and Smith 2003). These bands are almost identical to three bands of the calcium antimonate $\mathrm{Ca}_{2} \mathrm{Sb}_{2} \mathrm{O}_{7}$ spectrum $(318,367,472,624,781$ and $821 \mathrm{~cm}^{-1}$, see Fig. $5 \mathrm{~b}, \mathrm{~d}$ ). The spectra of both can be distinguished, however, by the intensity proportions of the specific bands and by the additional bands of calcium antimonate.

Manganese oxide crystals, most probably $\gamma-\mathrm{MnO}_{2}$ have been detected in the Mn-rich dark centre of sample 103. Characteristic Raman bands are at 243, 342, 384, 496, 562,634 and $736 \mathrm{~cm}^{-1}$ (Fig. 9) (Julien et al. 2002).

\section{Discussion and conclusions}

As a result of the present study, the four questions asked at the beginning may be answered as follows:

1. All the differently coloured parts of 11 of the investigated fragments show the typical Roman glass recipe, if additional elements are subtracted from the analyses and the basical elements are normalised to $100 \%$. This indicates that Roman glassmakers used a standard glass recipe, which was modified by the addition of various colourants, opacifying agents and further elements to produce certain special effects. The fragments are formed by a sodium-calcium-silicateglass. Particularly, the low contents of $\mathrm{K}, \mathrm{Mg}$ and $\mathrm{P}$ substantiate the use of Na-minerals from Wadi Natrun instead of plant ashes as a flux material, most indicative for glass production in the Roman Empire. The preferred flux mineral from Wadi Natrun is Trona $\mathrm{Na}_{3} \mathrm{H}\left(\mathrm{CO}_{3}\right)_{2} 2 \mathrm{H}_{2} \mathrm{O}$ (Wedepohl 2003), but noteworthy contents of $\mathrm{Cl}$ up to $1.3 \mathrm{wt} . \%$ in the glass matrix of the fragments and a positive correlation of $\mathrm{Cl}$ and $\mathrm{Na}$ also point to the use of $\mathrm{NaCl}$ in shares up to $2 \%$, either intentionally added or as impurity of the Trona.

2. Sample 103 differs clearly from all the other fragments in several points. One major difference is the $\mathrm{K}$ pronounced composition of the basic recipe. $\mathrm{K}$ from tree ashes as a flux material was introduced into glass technology in the early Middle Ages (Wedepohl 2003).
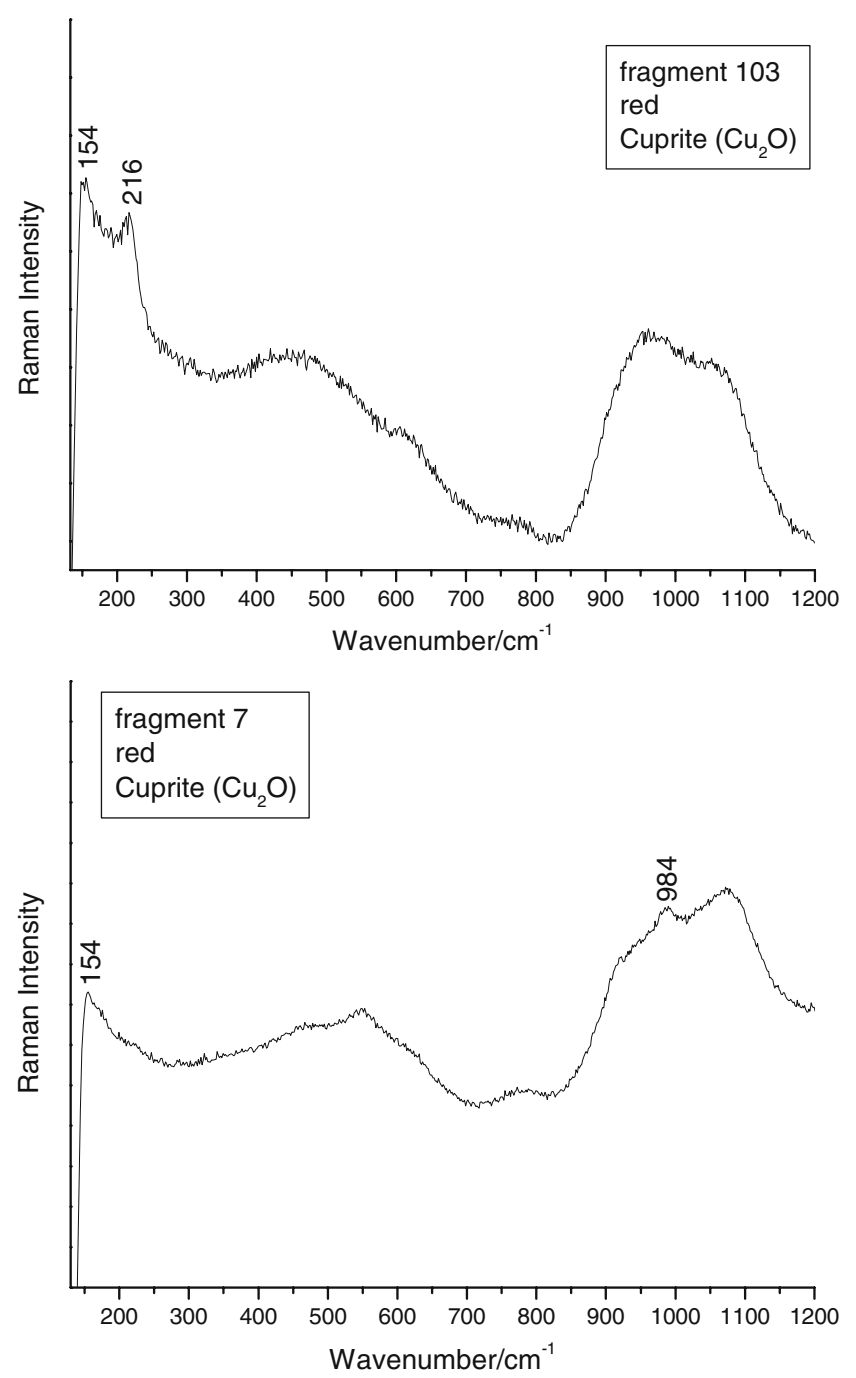

Fig. 7 Raman-spectrum of cuprite as a red-colouring agent in fragment 103 and in fragment 7 together with the typical band for lead glass at $984 \mathrm{~cm}^{-1}$ 


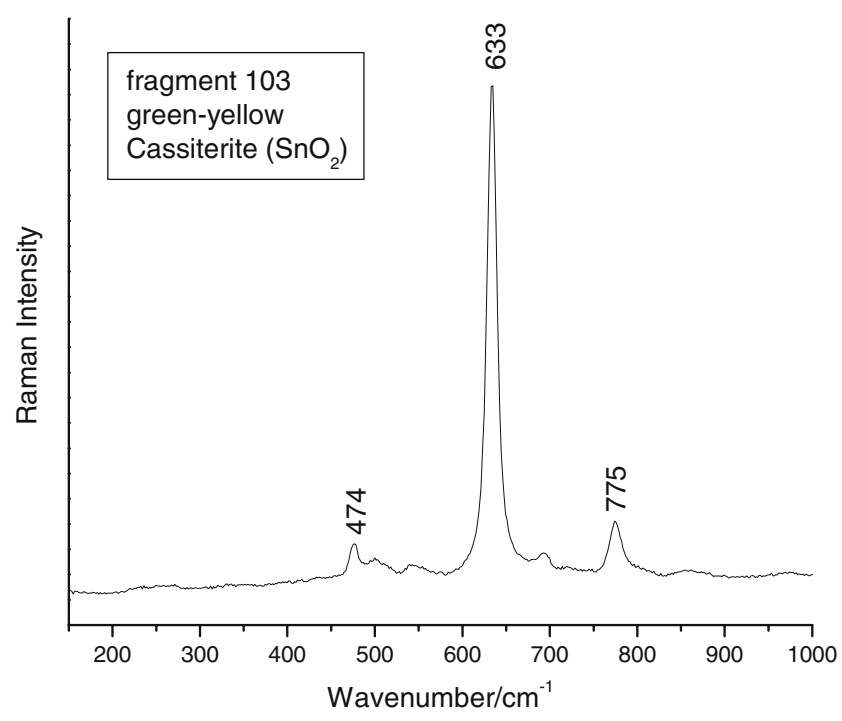

Fig. 8 Raman-spectrum of cassiterite as opacifier in the green-yellow parts of fragment 103

Normally, however, glass containing tree ashes has low contents of $\mathrm{Na}_{2} \mathrm{O}$, in most cases below $2 \%$, which is not the case for fragment 103 with $\mathrm{Na}_{2} \mathrm{O}$ contents around 6\%. Nevertheless, such mixed glasses were also produced during the Middle Ages, most probably by recycling Na-rich and K-rich glass shards. $\mathrm{K}-\mathrm{Na}$ mixed glass is reported from medieval glass factories, but also from excavation finds (Bruckschen 2000; Schüssler and Lang 2002; Brinker and Schüssler 2003). Concerning the colours of fragment 103, the dark core is dominated by $\mathrm{Mn}$ together with crystals of $\mathrm{MnO}_{2}$. This mineral was not known as a colouring agent in antiquity, but was used as a brown colourant during the Middle Ages, i.e. for church windows and for glazing of apulian ceramics (Clark et al. 1997; Wedepohl 2003). The green part of the fragment contains cassiterite as opacifier. This was not used in antiquity before the second century AD (Turner and Rooksby 1961). Cassiterite is a colourant, which from that time on was commonly utilised to achieve white colours (socalled tin-white). Interestingly, the white glass of fragment 103 was not coloured by use of cassiterite, but calcium antimonate. The $\mathrm{PbO}$ content of the red opaque glass, 26 wt.\%, exceeds clearly the $\mathrm{PbO}$ values $<10 \mathrm{wt} . \%$ in red glasses of the other fragments. The Co content of the blue part is more than three times higher than in the other blue glasses. Minor As contents qualitatively detected in the blue glass of fragment 103 point to the use of Co from As-rich Co ore. Such ore presumably derives from the As-bearing Co deposit of Schneeberg in Germany which was earliest mined since 1520 (Geilmann 1962). From all these compositional differences it becomes clear that fragment 103 does not correspond to the other fragments. Fragment 103 is assumed to derive from glass production of the Middle Ages or even younger periods.

3. In terms of their stylistic provenance, no significant differences could be recognised between the three different types (1) Hellenistic type, (2) Ptolemaic and Romano-Egyptian period type and (3) early imperial period type, regarding the oxides of the basical recipe: $\mathrm{SiO}_{2}, \mathrm{Al}_{2} \mathrm{O}_{3}, \mathrm{CaO}, \mathrm{K}_{2} \mathrm{O}, \mathrm{Na}_{2} \mathrm{O}$, if normalised to $100 \%$. Within $1 \sigma$ standard deviation, the contents are similar for the different stylistic types. Concerning the additional elements of the colourants and opacifyers, the broad distribution of contents does not allow for a chemical distinction of the stylistic types. Hereby, the $\mathrm{PbO}$ contents of the yellow glasses between $16 \%$ and $30 \%$ in (1) and (2) and generally below $11 \%$ in (3) form an exception. There is also a tendency to higher $\mathrm{PbO} / \mathrm{Sb}_{2} \mathrm{O}_{3}$ ratios above 10 in (1) and (2) and to ratios below 10 in (3). $\mathrm{Cl}$ contents $>1 \%$ in the yellow and the white glass parts of (3) tend to be enriched compared to the contents $<0.7 \%$ in (1) and (2). These weak differences may indicate a slight variation of the recipes with time, region or glassmaking studio and, in case of $\mathrm{Cl}$, the use of more impure Trona for (3).

4. The colours of the mosaic glass are effected either by addition of ionic agents or by colouring and opacifying crystals or by a mixture of both. Thereby $\mathrm{Mn}^{3+}$ is responsible for purple, $\mathrm{Co}^{2+}$ for deep blue, $\mathrm{Cu}^{2+}$ for light blue and $\mathrm{Fe}^{3+}$ for yellow-brown translucent colours, calcium antimonates for white opaque, lead antimonate for yellow opaque and cuprite for red opaque glass. The use of trivalent $\mathrm{Mn}$ and calcium antimonate as colouring agents seem to be widespread

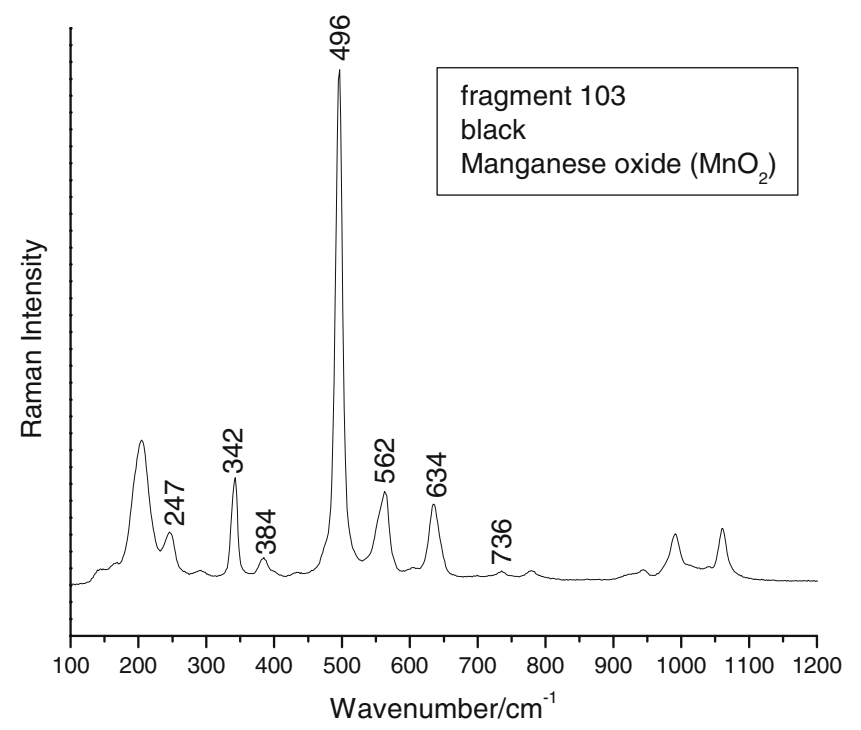

Fig. 9 Raman-spectrum of $\mathrm{MnO}_{2}$ as a dark-colouring agent in fragment 103 
in Roman glass production, i.e. the making of Roman cameo glass (Weiß and Schüssler 2000).

Doping of translucent colours with calcium antimonates produces opaque glass of more or less the same colour or, alternatively, of a mixed colour, if high amounts of the crystals are used. Various green colours are either produced by stratification of translucent blue superimposed to opaque yellow colours, or by mixing of translucent blue with leadantimonate, or by mixing of $\mathrm{Cu}$ and $\mathrm{Pb}$, in cases with additional colouring crystals.

The differently coloured glass parts of the 11 fragments display unsystematically distributed $\mathrm{Pb}$ contents. For example, half of the white glasses contain $\mathrm{PbO}$ at the detection limit, the others show values between 0.7 and 12.5 wt.\%. Beside $\mathrm{Na}, \mathrm{Pb}$ was certainly used for further reduction of the melting temperature. But $\mathrm{Pb}$ is also responsible for the yellow and, together with $\mathrm{Cu}$, the green colour of glass. It also acts as a stabiliser for colouring crystals, as particularly shown for the red opaque glass (Freestone 1987; Wedepohl 2003).

All the samples coloured by $\mathrm{Cu}$ contain minor amounts of $\mathrm{SnO}_{2}$ between 0.09 and 0.63 wt.\%. This is taken as an indicator for the use of bronze instead of pure copper as an admixture to the glass melt. The composition of the bronze may be recalculated, assuming $\mathrm{Sn}+\mathrm{Cu}$ of the glass $=100 \%$ of the bronze: the $\mathrm{Sn}$ content of the suspected bronze was $14.8 \%, 11.3 \%, 4.9 \%, 8.8 \%, 14.5 \%, 10.5 \%$ and $4.9 \%$ for the samples 2 (blue), 7 (green), 33 (red), 78 (cyan), 78 (red), 83 (blue) and 93 (blue), respectively. The Sn-content of ancient bronze in general varies between $5 \%$ and $30 \%$ (Blümner 1969). The red part of fragment 7 contains more $\mathrm{SnO}_{2}$ than $\mathrm{CuO}$ which does not match a bronze admixture. The $\mathrm{SnO}_{2}$-content (10.2 wt.\%) of the green glass in sample 103 exceeds by far the $\mathrm{CuO}$ content of $3.1 \mathrm{wt} . \%$; in this case further $\mathrm{SnO}_{2}$ was intentionally added to produce the cassiterite.

Acknowledgements Volker von Seckendorff managed the taking of backscattered electron images at the Institute of Mineralogy, Erlangen University. Klaus-Peter Kelber, Institute of Geography, Würzburg University, took the pictures of Fig. 1. Ulrich Sinn and Irma Wehgartner, Institute of Archaeology and Martin von Wagner Museum, Würzburg University, facilitated the investigation of the glass fragments and contributed helpful discussions. Simona Quartieri, University of Messina, and an anonymous colleague carefully reviewed the manuscript. Tobias Langenhan critically read the manuscript and did some language correction. Thank you for all this kind assistance.

\section{References}

Bimson M, Freestone IC (1988) An analytical studie of the relationship between the Portland Vase and other Roman cameo glasses. J Glass Studies 30:55-64
Blümner H (1969) Technologie und Terminologie der Gewerbe und Künste bei Griechen und Römern IV. Teubner, Leipzig

Bouchard M, Smith DC (2003) Catalogue of 45 reference Raman spectra of minerals concerning research in art history or archaeology, especially on corroded metals and coloured glass. Spectrochim Acta 59A:2247-2266

Braun C (1983) Analysen von Gläsern aus der Hallstadtzeit mit einem Exkurs über römische Fenstergläser. In: Frey O (ed) Glasperlen der vorrömischen Eisenzeit I. Marburger Studien zur Vor-und Frühgeschichte 5:129-175

Brill RH (1999) Chemical analyses of early glasses, vol. II the tables. The Corning Museum of Glass, Corning

Brill RH, Cahill ND (1988) A red opaque glass from Sardis and some thoughts on red opaques in general. J Glass Studies $30: 16-27$

Brinker B, Schüssler U (2003) Spätmittelalterliche Glasproduktion im Schönbuch bei Tübingen. In: Steppuhn S (ed) Glashütten im Gespräch. Schmidt-Römhild, Lübek, pp 39-45

Bruckschen M (2000) Faszinazion Glas. Die Braunschweiger Bodenfunde aus dem Mittelalter und der frühen Neuzeit. Dr Thesis, University Kiel

Clark RJH, Cridland L, Kariuki BM, Harris KDM, Withnall RJ (1995) Synthesis, structural characterization and Raman-spectroscopy of the inorganic pigments lead-tin yellow type-I and type-II and lead antimonate yellow - their identification on medieval paintings and manuscripts. J Chem Soc Dalton Trans 16:25772582

Clark RJH, Curri L, Henshaw GS (1997) Characterisation of brownblack and blue pigments in glazed pottery fragments from Castel Fiorentino (Foggia, Italy) by Raman microscopy, X-ray powder diffraction and X-ray photoelectron spectroscopy. J Raman Spectrosc 28:105-109

Colomban P, March G, Mazerolles L, Karmous T, Ayed N, Ennabli A, Slim HJ (2003) Raman identification of materials used for jewellery and mosaics in Ifriqiya. J Raman Spectrosc 34:205213

Freestone IC (1987) Composition and microstructure of early opaque red glass. In: Bimson M, Freestone IC (eds) Early vitreous materials. Br Mus Occas Pap 56:173-190

Gedzevičiūte V (2006) Die Mosaikgläser des Martin von Wagner Museums-archäologische und materialkundliche Untersuchungen. Magister Thesis, University Würzburg

Geilmann W (1962) Beiträge zur Kenntnis alter Gläser VII Kobalt als Färbungsmittel. Glastech Ber 35:186-192

Goldstein SM (1979) Pre-Roman and Early Roman glass in the Corning Museum of Glass. Corning Museum of Glass, Corning, NY.

Grose DF (1989) The Toledo Museum of Art—early ancient glass. Hudson Hills, New York

Harding RR, Hornytzkyi S, Date AR (1989) The composition of an opaque red glass used by Fabergé. J Gemm 21:275-287

Henderson J (1985) The raw materials of early glass production. Oxf J Archaeol 4:267-291

Husson E, Repelin Y, Vandenborre MT (1984) Spectres de vibration et champ de force de l'antimonate et de l'arséniate de calcium $\mathrm{CaSb}_{2} \mathrm{O}_{6}$ et $\mathrm{CaAs}_{2} \mathrm{O}_{6}$. Spectrochim Acta 40A:1017-1020

Julien C, Massot M, Rangan S, Lemal M, Guyomard DJ (2002) Study of structural defects in $\gamma-\mathrm{MnO}_{2}$ by Raman spectroscopy. J Raman Spectrose 33:223-228

Kurzmann P (2003) Archäochemische Untersuchungen an mittelalterlichem Glas: Über "farbloses" Glas und Knochenasche-Glas. In: Steppuhn S (ed) Glashütten im Gespräch. Schmidt-Römhild, Lübek, pp 46-49

Lierke R (1999) Antike Glastöpferei, ein vergessenes Kapitel der Glasgeschichte. Phillip von Zabern, Mainz

Mass LJ, Wypyski MT, Stone RE (2002) Malkata and Lisht glassmaking technologies: towards a specific link between 
second millennium BC metallurgists and glassmakers. Archaeometry $44: 62-82$

Möbius H (1962) Antike Kunstwerke aus dem Martin von Wagner Museum. Erwerbungen 1945-1961. Stürtz AG, Würzburg

Oliver A (1968) Millefiori glass in classical antiquity. J Glass Studies 10:48-70

Rottländer RCA (1990) Naturwissenschaftliche Untersuchungen zum römischen Glas in Köln. Kölner Jb Vor-und Frühgeschichte 23:563-581

Scholze H (1988) Glas: Natur, Struktur, Eigenschaften. Springer, Berlin Heidelberg, NY

Schüssler U, Lang W (2002) Mineralogische Untersuchungen zu Produktionseinrichtungen und Produkten der spätmittelalterlichen Glashütte "Salzwiesen" im Nassachtal bei Uhingen. Hohenstaufen Helfenstein Hist Jb Kr Göppingen 12:31-58

Sellner C, Oel HJ, Camara B (1979) Untersuchungen alter Gläser (Waldglas) auf Zusammenhang von Zusammensetzung, Farbe und Schmelzatmosphäre mit der Elektronenspektroskopie und der Elektronenspinresonanz (ESR). Glastech Ber 52:255-264

Shortland AJ (2002) The use and origin of antimonate colorants in early Egyptian glass. Archaeometry 44:517-530

Stern EM, Schlick-Nolte B (1994) Frühes Glas der alten Welt. Sammlung Ernesto Wolf. Hatje, Stuttgart
Turner WES, Rooksby HP (1961) Further historical studies based on $\mathrm{X}$-ray diffraction methods of the reagents employed in making opal and opaque glasses. Jb RGZM 8:1-6

Velde B, Gendron C (1980) Chemical composition of some GalloRoman glass fragments from Central Western France. Archaeometry 22:183-187

Velde B, Sennequier G (1985) Observations on the chemical composition of several types of Gallo-Roman and Frankish glass production. Annales 9e Congrès de l'AIHV, 127-147

Verità M, Toninato T (1990) Riscontri analitici sulle origini della vetraria Veneziana. Contributi Storico-Tecnici 1. Comitato Nazionale Italiano AIHV

Wedepohl KH (2003) Glas in der Antike und im Mittelalter. Geschichte eines Werkstoffs. Schweizerbart, Stuttgart

Weiß C, Schüssler U (2000) Kameoglasfragmente im Martin von Wagner Museum der Universität Würzburg und im Allard Pierson Museum Amsterdam. Jb Dt Arch Inst 115:199-251

Welter N, Schüssler U, Kiefer WJ (2007) Characterisation of inorganic pigments in ancient glass beads by means of Raman microspectroscopy, microprobe analysis and X-ray diffractometry. J Raman Spectrosc 38:113-121

Weyl WA (1953) Coloured glass. Soc Glass Technology, Sheffield 